Research Paper

\title{
Aloe-emodin inhibits HER-2 expression through the downregulation of $Y$-box binding protein-1 in HER-2-overexpressing human breast cancer cells
}

This article has been corrected. Correction in: Oncotarget. 2019; 10:5727-5729.

\author{
Jui-Wen Ma ${ }^{1}$, Chao-Ming Hung ${ }^{2,3}$, Ying-Chao Lin ${ }^{4,5,6}$, Chi-Tang Ho${ }^{7}$, Jung-Yie Kao ${ }^{1}$, \\ Tzong-Der Way ${ }^{8,9}$ \\ ${ }^{1}$ Institute of Biochemistry, College of Life Science, National Chung Hsing University, Taichung, Taiwan \\ ${ }^{2}$ Department of General Surgery, E-Da Hospital, I-Shou University, Kaohsiung, Taiwan \\ ${ }^{3}$ School of Medicine, I-Shou University, Kaohsiung, Taiwan \\ ${ }^{4}$ Division of Neurosurgery, Buddhist Tzu Chi General Hospital, Taichung Branch, Taiwan \\ ${ }^{5}$ School of Medicine, Tzu Chi University, Hualien, Taiwan \\ ${ }^{6}$ Department of Medical Imaging and Radiological Science, Central Taiwan University of Science and Technology, Taichung, \\ Taiwan \\ ${ }^{7}$ Department of Food Science, Rutgers University, New Brunswick, New Jersey, USA \\ ${ }^{8}$ Department of Biological Science and Technology, College of Biopharmaceutical and Food Sciences, China Medical University, \\ Taichung, Taiwan \\ ${ }^{9}$ Department of Health and Nutrition Biotechnology, College of Health Science, Asia University, Taichung, Taiwan \\ Correspondence to: Tzong-Der Way, email: tdway@mail.cmu.edu.tw \\ Jung-Yie Kao, email: biosjyk@gmail.com
}

Keywords: HER-2-overexpressing breast cancer cells, aloe-emodin, Y-box binding protein-1, ILK/Akt/mTOR signaling pathway, epithelial-mesenchymal transition

Received: January 06, 2016

Accepted: June 12, 2016

Published: July 06, 2016

\section{ABSTRACT}

Human epidermal growth factor receptor-2 (HER-2)-positive breast cancer tends to be aggressive, highly metastatic, and drug resistant and spreads rapidly. Studies have indicated that emodin inhibits HER-2 expression. This study compared the HER2-inhibitory effects of two compounds extracted from rhubarb roots: aloe-emodin (AE) and rhein. Our results indicated that $A E$ exerted the most potent inhibitory effect on HER-2 expression. Treatment of HER-2-overexpressing breast cancer cells with AE reduced tumor initiation, cell migration, and cell invasion. AE was able to suppress YB-1 expression, further suppressing downstream HER-2 expression. AE suppressed YB-1 expression through the inhibition of Twist in HER-2-overexpressing breast cancer cells. Our data also found that AE inhibited cancer metastasis and cancer stem cells through the inhibition of EMT. Interestingly, AE suppressed YB-1 expression through the downregulation of the intracellular integrin-linked kinase (ILK)/protein kinase B (Akt)/mTOR signaling pathway in HER-2-overexpressing breast cancer cells. In vivo study showed the positive result of antitumor activity of $A E$ in nude mice injected with human HER-2-overexpressing breast cancer cells. These findings suggest the possible application of AE in the treatment of HER-2-positive breast cancer.

\section{INTRODUCTION}

Breast cancer is the most common cancer among women worldwide [1]. Among the clinical classifications of breast cancer [2], human epidermal growth factor receptor-2 (HER-2)-overexpressing breast cancer has a high risk of treatment failure because it spreads rapidly and is highly metastatic as well as drug resistant [3]. Clinically, Herceptin is the most common treatment [4]; however, some patients exhibit drug resistance within 1 year of treatment [5]. Therefore, overcoming drug resistance and establishing more effective treatment options for patients with HER-2 overexpression is crucial [6]. 
Epithelial-mesenchymal transition (EMT) is a key event in cancer metastasis [7]. Tumor hypoxia results in the high expression of hypoxia-inducible factors (HIFs), thereby inducing EMT [8]. After EMT induction, the transcription factors Snail or Twist suppresses the intercellular binding protein E-cadherin, reducing binding between cancer cells and generating highly aggressive and mobile cancer cells; this promotes the departure of cancer cells from the primary tumor, leading to tumor metastasis [9]. EMT can induce the generation of cancer cells with stem cell characteristics [10], and cancer stem cells are one of the most crucial factors in cancer recurrence, metastasis, and drug resistance [11].

Y-box binding protein 1 (YB-1) is a multifunctional protein involved in transcription and translation; high YB-1 expression promotes cell proliferation and inhibits apoptosis, tumor invasion and metastasis, and angiogenesis [12]. Studies have found that YB-1 can promote breast cancer, bladder cancer, liver cancer, and progression and metastasis of other cancers [13] through EMT regulation. YB-1 expression, which has been detected in many cancers, promotes stem cell expression, improves mobility of cancer cells, and enhances expression of genes associated with drug resistance and other common characteristics of cancer stem cells [14-16].

Anthraquinones are a large group of natural aromatic compounds [17]. Such compounds are historically used as natural dyes, but recent studies demonstrated their medicinal values such as antibacterial, anti-inflammatory, antiviral, anticancer, and antiaging properties [18]. The anthraquinone emodin inhibits the proliferation of HER2-overexpressing breast cancer cells [19] and induces apoptosis of cancer cells [20]. However, it is not known whether other anthraquinones, such as aloe-emodin (AE) and rhein, would suppress the proliferation of HER-2overexpressing breast cancer cells. This study revealed that anthraquinones suppressed HER-2-overexpressing breast cancer cell proliferation; furthermore, the molecular changes during cell program death were explored.

\section{RESULTS}

\section{Anthraquinone derivatives suppressed HER-2 expression and cell proliferation in HER-2- overexpressing breast cancer cells}

Studies have demonstrated that emodin, an anthraquinone compound, has antitumor effects in breast cancer [21]. In this study, we compared the inhibitory effects of three anthraquinones, emodin, AE, and rhein, (Figure 1A) on HER-2 expression in HER-2-overexpressing breast cancer cells. Among these three anthraquinones, AE had the highest inhibitory effect on HER-2 expression in SkBr3, BT-474, and MDA-MB-453 cell lines when they were treated with these compounds at a concentration of $40 \mu \mathrm{M}$ for 48 $\mathrm{h}$ (Figure 1B). Immunofluorescence staining yielded similar results (Figure $1 \mathrm{C}$ ). In a cell viability test, AE suppressed HER-2 expression in HER-2-overexpressing $\mathrm{SkBr} 3$ cell line (Figure 1D). In the soft agar assay, AE reduced the number of cells (Figure 1E). In the colony formation assay, AE had the highest inhibitory effect on the number of colonies, compared with emodin and rhein (Figure 1F). These findings showed that among anthraquinones, AE had the most significant suppressive effect on HER-2 expression and cell proliferation in HER-2-overexpressing breast cancer cells. Therefore, in subsequent experiments, we treated $\mathrm{SkBr} 3$ cells with different concentrations of $\mathrm{AE}(10,20$, and $40 \mu \mathrm{M}$ ) and observed the variation in the suppression of HER-2 expression. The Western blotting results showed that increasing AE therapeutic concentrations significantly and dose-dependently suppressed HER-2 expression (Figure 1G). Immunofluorescence staining also yielded similar results (Figure $1 \mathrm{H}$ ). These results showed that compared with emodin and rhein, AE significantly suppressed HER-2 expression in HER-2-overexpressing breast cancer cells.

\section{AE specifically suppressed cell proliferation and induced apoptosis in HER-2-overexpressing breast cancer cells}

Among members of the epidermal growth factor receptor (HER, ErbB) family, HER-2 is the most potent oncogenic protein and positively correlates with the metastasis of cancer cells [22]. We next investigated whether AE specifically suppressed the proliferation of HER-2-overexpressing breast cancer cells. We used the MTT assay to examine the cell viability of different cell lines, including the estrogen receptor (ER)-positive, triplenegative breast cancer (TNBC), HER-2-overexpressing, and normal breast cell line, MCF-10A. After treatment with different concentrations of $\mathrm{AE}$ for $48 \mathrm{~h}$, the results indicated that AE specifically suppressed the proliferation of HER2-overexpressing cells (Figure 2A). The colony formation test also revealed the same result (Figure 2B). Furthermore, ER-positive and triple-negative breast cancer cells were transfected with HER2 to determine whether AE specifically suppresses the proliferation of HER-2-overexpressing cells. We used Western blotting to verify HER-2 overexpression in ER-overexpressing and triple-negative breast cancer cell lines (data not shown); moreover, we used the MTT test to compare cell transfection in HER-2-overexpressing and HER-2-non-overexpressing cell lines. We found that as the AE concentration increased, cell proliferation in the HER2-overexpressing cell line decreased (Figure 2C). Moreover, the colony formation test yielded similar results (Figure 2D). The MTT assay revealed that AE treatment at different time points suppressed cell viability in $\mathrm{SkBr} 3$ cells $\left(24 \mathrm{~h}, \mathrm{IC}_{50}=\right.$ $152.88 \mu \mathrm{M} ; 48 \mathrm{~h}, \mathrm{IC}_{50}=27.56 \mu \mathrm{M}, 72 \mathrm{~h}, \mathrm{IC}_{50}=16.72 \mu \mathrm{M}$ ) (Figure 2E). The soft agar test showed that treatment with 
A
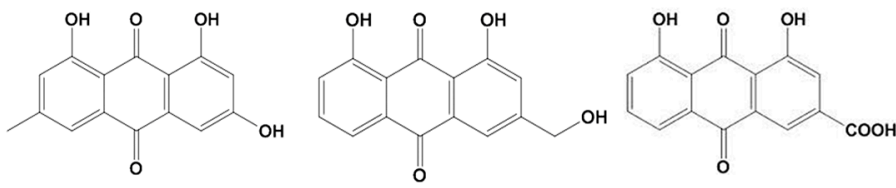

Emodin (Em)

Aloe-emodin (AE)

Rhein (Rh)

B

SkBr3

BT-474

MDA-MB-453

\begin{tabular}{|c|c|c|c|c|}
\hline & CTL & Em & $\mathrm{AE}$ & $\mathbf{R h}$ \\
\hline R- & & & & \\
\hline & & 0.56 & 0.11 & 0.78 \\
\hline
\end{tabular}

\begin{tabular}{|llll|}
\hline CTL & Em & AE & Rh \\
\hline & & & \\
\hline 1.00 & 0.49 & 0.12 & 0.71 \\
\hline & & & \\
\hline
\end{tabular}

CTL Em AE Rh $(40 \mu \mathrm{M})$

C

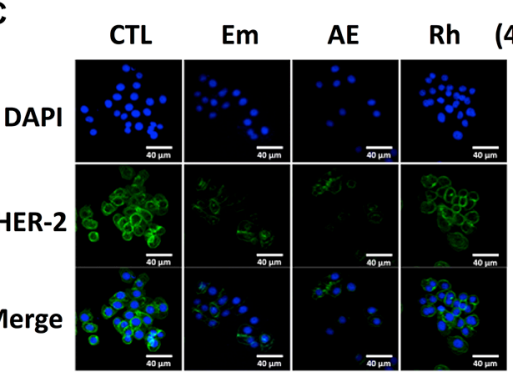

D

E
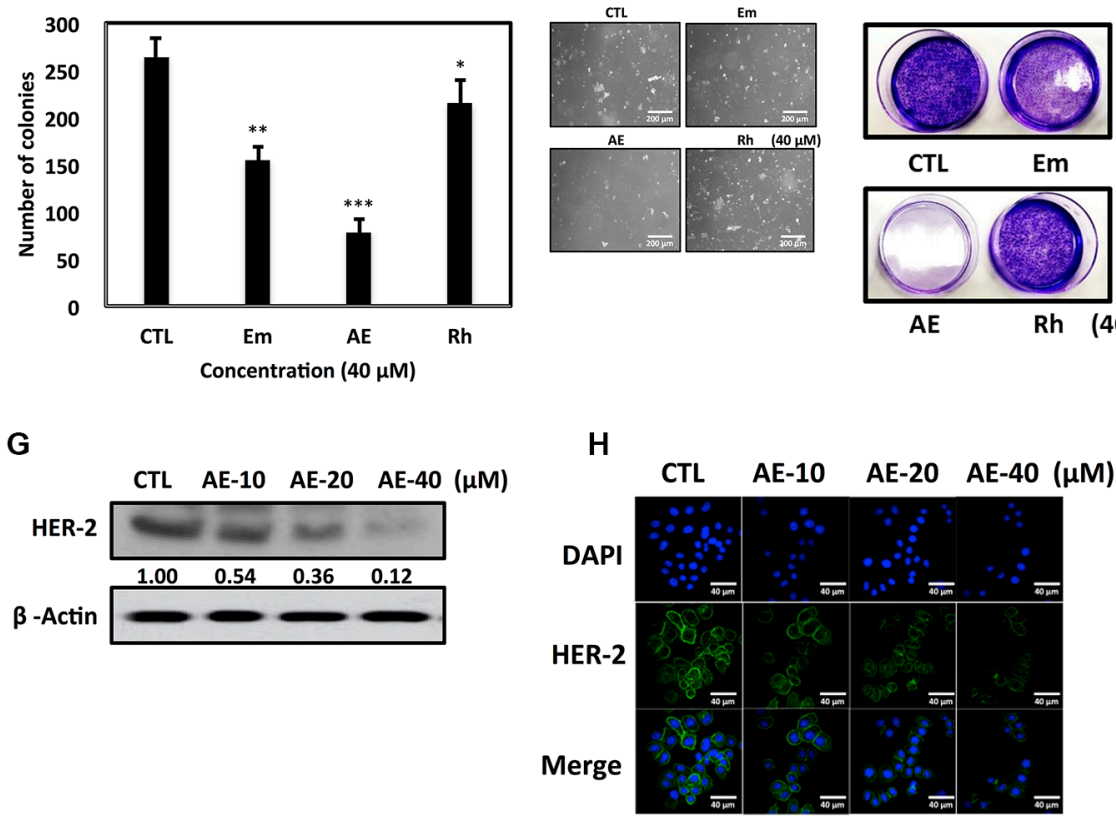

Figure 1: Effect of emodin, aloe-emodin and rhein on HER-2 expression in HER-2-overexpressing breast cancer cells. (A) Structures of emodin (Em), aloe-emodin (AE) and rhein (Rh). (B) Cells were treated with $40 \mu \mathrm{M}$ Em, AE and Rh for $48 \mathrm{~h}$. Cell lysates were immunoblotted with anti-HER-2 antibody. $\beta$-Actin was used as the loading control. (C) Cells were treated with $40 \mu \mathrm{M}$ Em, AE, and $\mathrm{Rh}$ for $48 \mathrm{~h}$. HER-2 was visualized through immunofluorescence staining using anti-HER-2 antibodies and Alexa Fluor ${ }^{\mathbb{B}}$-conjugated secondary antibodies (green). Labeling nuclear DNA using DAPI (blue). Scale bar, $40 \mu \mathrm{m}$. (D) Effect of Em, AE, and Rh on viability of HER-2 overexpressing breast cancer cells. The $\mathrm{SkBr} 3$ cell line was treated with various concentrations of Em, $\mathrm{AE}$, and $\mathrm{Rh}$ at $37^{\circ} \mathrm{C}$ for $48 \mathrm{~h}$. The effect on cell growth was examined using the MTT assay, and the percentage of cell viability was calculated by defining the absorption of cells without Em, AE, or Rh as $100 \%$. (E) Anchorage-independent cell growth on soft agar. SkBr3 cells were grown on soft agar for 21 days in the presence of the $40 \mu \mathrm{M} \mathrm{Em,} \mathrm{AE,} \mathrm{and} \mathrm{Rh}(20 \times)$. Statistical analysis of the experiment. Columns, mean $(n=5)$; bars, SD. (F) In the colony formation assay, SkBr3 cells were treated with $40 \mu \mathrm{M} \mathrm{Em}, \mathrm{AE}$ and $\mathrm{Rh}$. (G) Cells were treated with various concentrations of $\mathrm{AE}$ for $48 \mathrm{~h}$. Cell lysates were immunoblotted with anti-HER-2 antibody. $\beta$-Actin was used as the loading control. (H) Immunofluorescence staining of HER-2 treated with various concentrations of AE. Each experiment was independently repeated three times $(n=3)$. The results are expressed as mean $\pm \mathrm{SD}$. $* P<0.05$. 
increasing concentrations of $\mathrm{AE}$ significantly reduced the number of colonies in $\mathrm{SkBr} 3$ cells (Figure 2F). In the colony formation assay, AE significantly reduced the number of colonies in SkBr3 cells (Figure 2G). Through Annexin V-PI double staining, we determined that $\mathrm{AE}$ induced apoptosis in $\mathrm{SkBr} 3$ cells (Figure $2 \mathrm{H}$ ). In addition, we determined the effect of AE on cell cycle arrest in HER-2-overexpressing cells through flow cytometry. These results indicated that $\mathrm{AE}$ treatment for $48 \mathrm{~h}$ significantly induced sub-G1 cell cycle arrest in $\mathrm{SkBr} 3$ cells (Figure 2I). When cells undergo apoptosis, PARP in the nucleus is cleaved to form cleaved PARP. This study observed that treatment with increasing concentrations of AE significantly increased cleaved PARP (Figure 2J). It showed that AE treatment specifically suppressed proliferation of HER-2-overexpressing cells by inducing apoptosis.

\section{AE suppressed YB-1 expression in SkBr3 cells}

A clinical study showed that YB-1 overexpression was detected in patients with HER-2 overexpression [23], and it also promoted cell proliferation, tumor metastasis, invasion and angiogenesis [24]. In this study, we determined whether AE suppressed YB-1 expression in HER-2-overexpressing cell lines. The results showed that increasing concentrations of AE more strongly suppressed YB-1 expression (Figure 3A). Similar results were obtained through immunofluorescence staining (Figure 3B). Moreover, we determined whether AE reduced YB-1 expression through transcription. We used qRT-PCR to observe mRNA levels. Our results showed that increasing concentrations of AE significantly increased the suppression of YB-1 mRNA levels. The results confirmed that AE suppressed YB-1 during transcription, which resulted in lower protein expression (Figure 3C). We next used siRNA to examine whether silencing of YB-1 expression affected HER-2 expression. The results showed that silencing YB-1 expression reduced HER-2 expression. Interestingly, silencing YB-1 expression and treating with AE suppressed HER-2 expression (Figure 3D). These results showed that in HER-2-overexpressing cell lines, suppression of YB-1 expression by AE further suppressed downstream HER-2 expression.

\section{AE downregulated Twist expression in SkBr3 cells}

Studies have indicated that Twist regulates YB-1 expression and both Twist and YB-1 promote malignant potentials, including tumor growth, invasion and anticancer-drug resistance $[25,26]$. We next determined whether AE suppressed YB-1 expression through the inhibition of Twist in HER-2-overexpressing breast cancer cells. Western blot results showed that increasing concentrations of $\mathrm{AE}$ significantly inhibited Twist expression (Figure 4A), and immunofluorescence staining yielded similar results (Figure
4B). We used qRT-PCR to investigate whether Twist mRNA levels changed after AE treatment. The results showed that increasing concentrations of AE significantly inhibited Twist mRNA levels (Figure 4C) and that AE treatment significantly inhibited the oncogenic transcription factor Twist through transcription. Our data indicated that treatment with $\mathrm{AE}$ suppressed YB-1 expression through the inhibition of Twist in HER-2-overexpressing breast cancer cells.

\section{AE inhibited epithelial-mesenchymal transition in $\mathrm{SkBr} 3$ cells}

Twist has been demonstrated to be a major regulator of EMT [27]. We evaluated whether AE inhibited EMT and cancer metastasis in HER-2-overexpressing cell lines. Our results showed that increasing concentrations of AE significantly restored the epithelial cell adhesion protein E-cadherin and suppressed vimentin expression, a mesenchymal cell marker. MDA-MB-231, which is a highly metastatic TNBC cell line, was used as the mesenchymal cell control (Figure 5A). Immunofluorescence staining of HER-2-overexpressing cell lines after AE treatment revealed significantly increased E-cadherin expression (Figure 5B). Interestingly, treatment of HER-2-overexpressing cell lines with AE significantly reduced the cancer metastasis transcription factors Snail, Slug, Twist, and HIF-1 $\alpha$ expression in a dose- (Figure 5C) and time-dependent (Supplementary Figure 1) manner. Malignant cells produce proteolytic enzymes, including serine proteinase, cathepsins, metalloproteinases (MMPs), and heparanase, among which MMP-9 and MMP-2 play key roles in destroying the basement membrane for mediating cancer invasion and metastasis [28]. The gelatin zymography assay confirmed that increasing concentrations of AE significantly reduced the activity of MMP-9 and MMP-2 in HER-2overexpressing cell lines (Figure 5D). The Transwells assay showed that treatment of HER-2-overexpressing cells with increasing concentrations of AE significantly inhibited the cancer cell migration (Figure 5E) and invasion (Figure 5F) rates. We determined whether AE treatment of HER-2overexpressing cancer cells inhibited cancer stem cells. The results showed that treatment of HER-2-overexpressing cells with increasing concentrations of AE significantly inhibited the number of mammosphere formation (Figure 5G) and the size of mammosphere formed (Figure $5 \mathrm{H}$ ). Therefore, we concluded that AE inhibited EMT involved in cancer metastasis and cancer stem cells.

\section{AE inhibited ILK signaling pathways in SkBr3 cells}

A study has indicated that altering the intracellular integrin-linked kinase (ILK)/protein kinase B (Akt)/ mTOR signaling pathway regulated YB-1 expression and/ or cellular localization [29]. We next observed whether AE treatment inhibited the expression of ILK. The results 
A

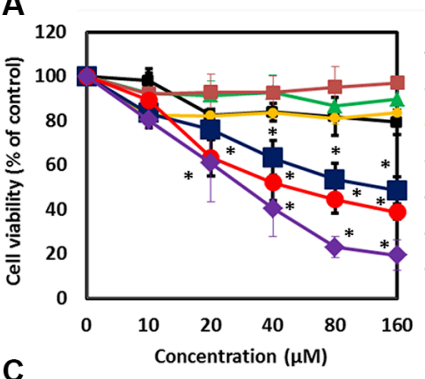

C

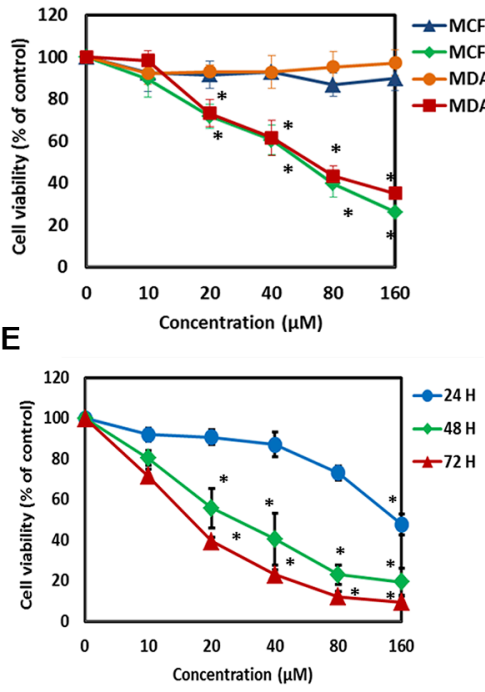

G

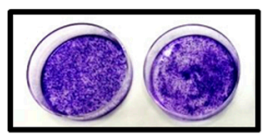

CTL AE-10

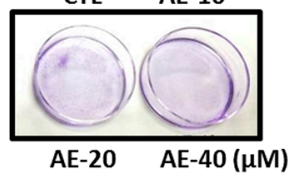

B

$\rightarrow-M C F-10 A$ (Normal)

$-\mathrm{MCF}-7$ (ER $\left.{ }^{+}\right)$

$\because$ BT-20 (TNBC)

-든-MDA-MB-231 (TNBC)

$\rightarrow-M D A-M B-453$ (HER-2+)

$\rightarrow-B T-474$ (HER-2 ${ }^{+}$)

$\rightarrow$ SkBr3 (HER-2 ${ }^{+}$)
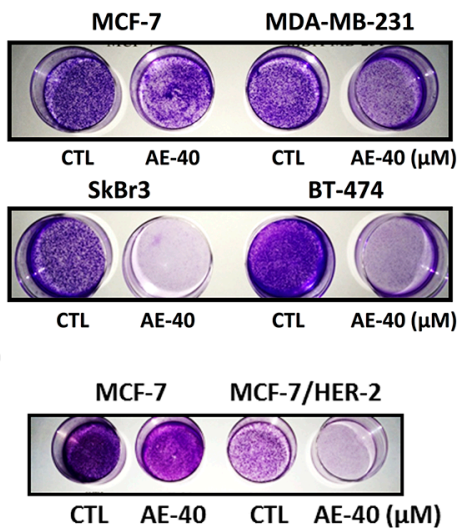

MDA-MB-231 MDA-MB-231/HER-2

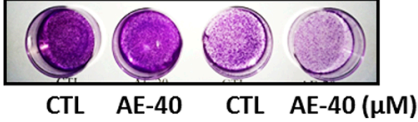

F

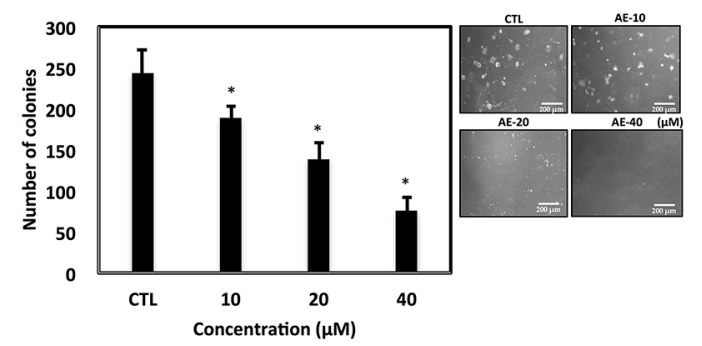

$\mathrm{H} \quad \mathrm{cI}$

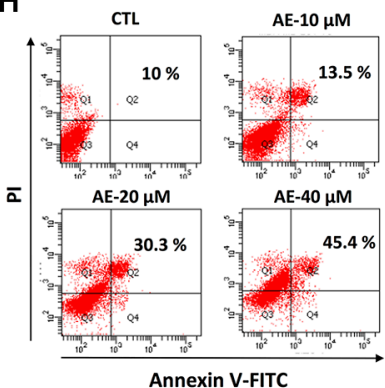

CTL AE-10 AE-20 AE-40 ( $\mu \mathrm{M})$

(I)

(l)

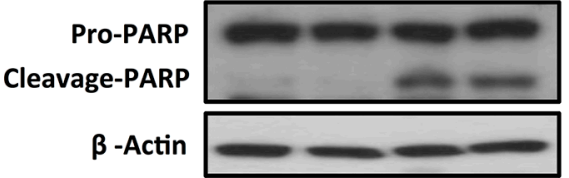

Figure 2: Aloe-emodin specifically inhibited cell proliferation and induced apoptosis in HER-2-overexpressing breast cancer cells. (A) Effect of AE on the cells viability of different breast cancer cell lines. Different cell lines were treated with various concentrations of $\mathrm{AE}$ at $37^{\circ} \mathrm{C}$ for $48 \mathrm{~h}$. The effect on cell growth was examined using the MTT assay. (B) In the colony formation assay, different breast cancer cell lines were treated with $40 \mu \mathrm{M}$ AE. (C) In comparison with MCF-7, MDA-MB-231 and HER-2-transfected cells (MCF-7/HER-2 and MDA-MB-231/HER-2). Cell viability was determined using the MTT assay. (D) These cell lines were treated with the same experimental conditions for investigating colony formation in the colony formation assay. (E) Effect of AE on the viability of HER-2-overexpressing breast cancer cells. The $\mathrm{SkBr} 3$ cell line was treated with various concentrations of $\mathrm{AE}$ at $37^{\circ} \mathrm{C}$ for 24,48 , and $72 \mathrm{~h}$. The effect on cell growth was examined using the MTT assay. (F) SkBr3 cells were treated with the same experimental conditions for anchorage-independent cell growth in soft agar. $(\mathbf{G})$ In the colony formation assay, $\mathrm{SkBr} 3$ cells were treated with various concentrations of $\mathrm{AE}$ at $37^{\circ} \mathrm{C}$ for $48 \mathrm{~h}$. (H) SkBr3 cells were treated with various concentrations of AE for $48 \mathrm{~h}$. Cells were stained with PI and FITCconjugated annexin V through flow cytometry. (I) Treatment of SkBr3 cells with various concentrations of AE for $48 \mathrm{~h}$, and PI-stained DNA content was analyzed through flow cytometry. (J) SkBr3 cells were treated with various concentrations of AE for $48 \mathrm{~h}$. Cells were then harvested and lysed for the detection of pro-PARP, cleaved PARP, and $\beta$-actin expression. Western blot data are representative of those obtained in at least three separate experiments. The results represent three repeated experiments and are expressed in mean \pm SD. Each experiment was independent repeated three times $(n=3) .{ }^{*} P<0.05$. 
showed that increasing concentrations of $\mathrm{AE}$ reduced ILK and phosphorylation of ILK at threonine 173 protein expression (Figure 6A). Next, the ILK inhibitor cdp-22 was used to treat HER-2-overexpressing breast cancer cell lines. Compared with treatment with AE or cdp-22 alone, the combined therapy more strongly inhibited phosphorylation of ILK and downstream HER-2, YB-1, and Twist protein expressions (Figure 6B). Extracellular growth factor and cell surface tyrosine receptor kinase activation resulted in PI3K activation, followed by phosphorylation of the downstream mTOR [30]. We investigated whether AE treatment inhibited the phosphorylation of Akt at serine 473 and mTOR at serine 2448. The results showed that increasing concentrations of $\mathrm{AE}$ reduced phosphorylation of Akt at serine 473 and mTOR at serine 2448 (Figure 6C). We confirmed these results through the use of constitutively active Akt (CA-Akt), which continued to phosphorylate Akt. The results confirmed that treatment with CA-Akt alone significantly increased Akt phosphorylation and downstream protein expression. Combining CA-Akt and $\mathrm{AE}$ treatment substantially restored the inhibition of $\mathrm{AE}$ in downstream proteins p-mTOR, HER-2, YB-1, and Twist (Figure 6D). Increased GSK3 $\beta$ phosphorylation has been shown to cause rapid cancer growth. Increasing concentrations of AE also inhibited GSK3 $\beta$ phosphorylation (Figure 6E). GSK3 $\beta$ inhibitor SB216763 was used to observe the effect of AE on downstream protein expression through the GSK3 $\beta$ pathway. The results showed that combined treatment more significantly inhibited GSK $3 \beta$ phosphorylation and downstream HER-2, YB-1, and Twist expressions (Figure 6F). Using nuclear/cytoplasmic separation techniques, we observed whether AE inhibited transport of transcription factors into the nucleus. The results showed that $\mathrm{AE}$ treatment for $24 \mathrm{~h}$ significantly inhibited the transport of Twist and YB-1 into the nucleus. PARP and $\beta$-tubulin were used as nucleus and cytoplasmic markers, respectively (Figure 6G). Thus, AE inhibited the expression of YB-1 through the ILK signaling pathway in HER-2-overexpressing cell lines.

\section{Antitumor activity of $\mathrm{AE}$ in $\mathrm{SkBr3}$ cell xenografts model}

Nude mice were injected with $3 \times 10^{6}$ HER-2overexpressing breast cancer cells for 14 days to induce the formation of solid tumors and were given AE once a
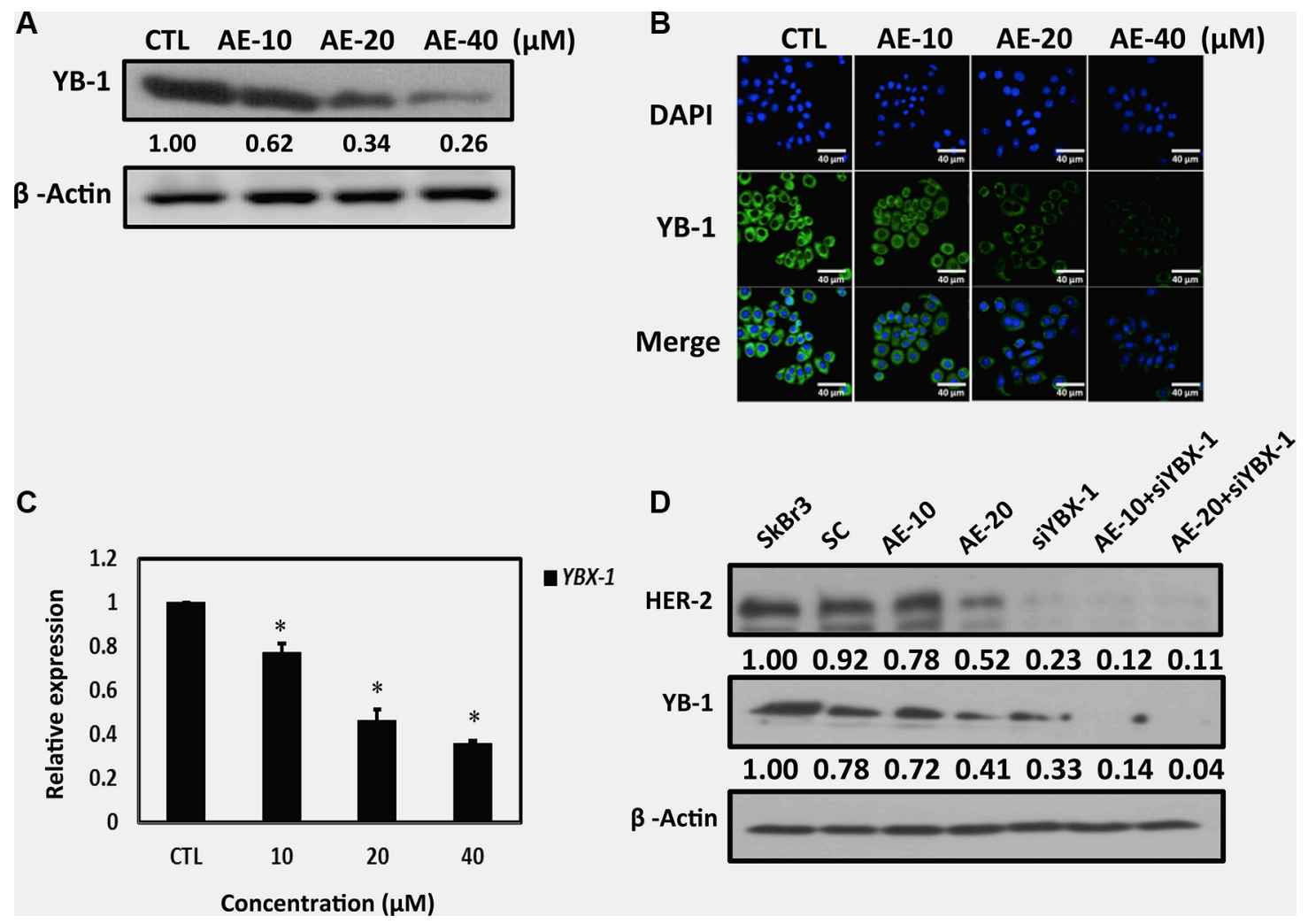

Figure 3: Aloe-emodin suppressed oncoprotein YB-1 expression in HER-2-overexpressing breast cancer cells. (A) $\mathrm{SkBr} 3$ cells were treated with various concentrations of $\mathrm{AE}$ for $48 \mathrm{~h}$. Cell lysates were immunoblotted with anti-YB-1 antibody. $\beta$-Actin was used as the loading control. (B) SkBr3 cells were treated with various concentrations of AE for 48 h. HER-2 was visualized through immunofluorescence staining using anti-HER-2 antibodies (green). Labeling nuclear DNA using DAPI (blue). Scale bar, $40 \mu \mathrm{m}$. (C) $\mathrm{SkBr} 3$ cells were treated with various concentrations of AE for $24 \mathrm{~h}$. The YB-1 mRNA levels were examined using real-time qPCR. Data are expressed in mean \pm SD. (D) SkBr3 cells were treated with various concentrations of AE for $48 \mathrm{~h}$ and transfected with YBX-1siRNA in combination with treatment with various concentrations of AE. Cell lysates were immunoblotted with anti-HER-2 and anti-YB-1 antibodies. $\beta$-Actin was used as the loading control. 
day for 5 consecutive days, and tumor size changes were observed twice weekly. AE significantly inhibited tumor size (Figure 7A). The tumors of representative mice showed the same result (Figure 7B). The tumors were removed to observe its appearance (Figure 7C) and weight (Figure 7D); increasing AE concentrations significantly inhibited tumor size and weight. Interestingly, AE did not cause weight loss in mice. (Figure 7E). We examined HER-2, YB-1, and E-cadherin expression in the tumor specimen through Western blotting. The results confirmed that AE treatment significantly reduced HER-2 and YB-1 oncogenic protein expression and restored epithelial cell adhesion protein E-cadherin expression (Figure 7F). Similar results were clearly observed in IHC staining; AE treatment significantly reduced HER-2, YB-1, and cell proliferation marker Ki67 expression (Figure 7G). Therefore, AE treatment significantly inhibited in vivo tumors.

\section{DISCUSSION}

HER-2 is found on the surface of all normal cells and receives signals for the regulation of cell growth [31]. However, in cancer cells, owing to gene amplification, many HER-2 receptor proteins are present on the surface of cells, leading to excessive growth of cells [32]. Cancer cells show rapid growth, division, and even more rapid metastasis. Compared with patients with early HER-2-overexpressing breast cancer, the probability of recurrence after resection is higher in patients with HER-2 overexpression, which accounts for approximately $25-30 \%$ of all breast cancer
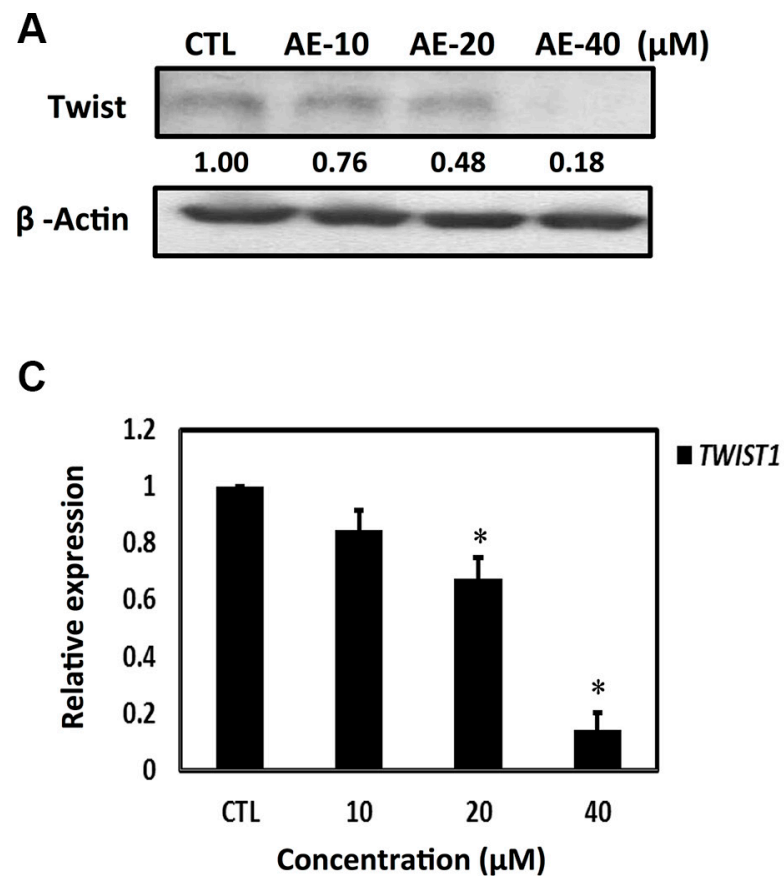

patients [33]. Due to the recurrence rate of HER-2overexpressing breast cancer, early HER-2 breast cancer treatment after surgery depends on the patient's condition; they can undergo hormone therapy, chemotherapy, or radiotherapy as adjuvant treatment [34]. The target agent therapy clearly influences relapse prevention of HER-2overexpressing breast cancer; therefore, the use of a target therapy as an adjuvant therapy is very crucial [35].

In recent years, much attention has been paid to the anti-tumor effect of emodin, with the main focus on neuroectodermal tumors, liver cancer, lung squamous cell carcinoma, merkel cell skin cancer, stomach cancer, and leukemia [36]. Emodin inhibits K562 leukemia cells and prolongs survival [37]. A possible mechanism is the inhibition of cancer cell DNA, RNA, and protein biosynthesis. AE (1,8-dihydroxy-3-(hydroxymethyl)-9,10anthracenedione) is a bioactive anthraquinone compound extracted from rhubarb roots. It effectively inhibits the proliferation of human colon cancer cell lines and induces apoptosis [38]. However, the inhibition of growth ability and mechanism of AE in HER-2-overexpressing cell lines are unclear. Therefore, we investigated the molecular mechanisms of the anthraquinone compounds inducing apoptosis of HER-2-overexpressing human breast cancer cell lines. In particular, we compared three anthraquinones, namely emodin, AE, and rhein, for HER2 inhibitory activity and the optimal AE concentration (Figure 1A-1D). We confirmed that AE treatment mainly reduced cancer cell viability by inducing apoptosis (Figure 2H-2J).

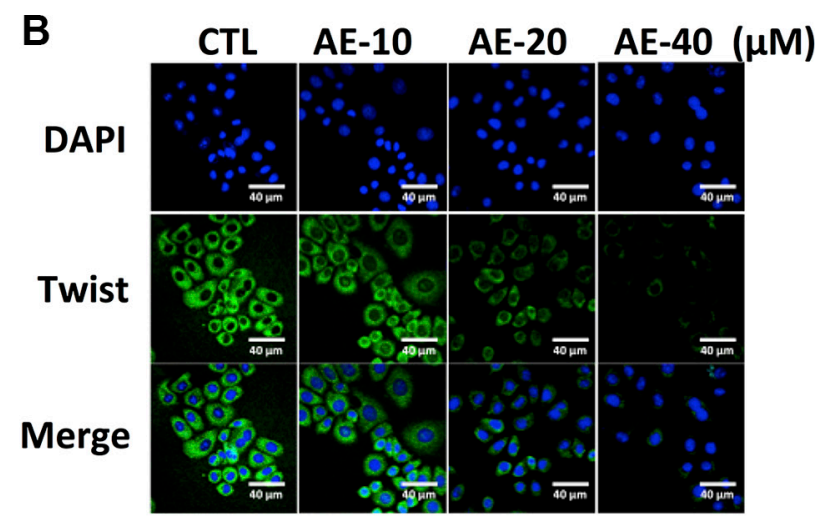

Figure 4: Aloe-emodin inhibited Twist expression in SkBr3 cells. (A) SkBr3 cells were treated with various concentrations of $\mathrm{AE}$ for $48 \mathrm{~h}$. Cell lysates were immunoblotted with anti-Twist antibody. (B) SkBr3 cells were treated with various concentrations of AE for $48 \mathrm{~h}$. Twist was visualized by immunofluorescence staining using anti-Twist antibodies (green). (C) SkBr3 cells were treated with various concentrations of AE for $24 \mathrm{~h}$. Twist mRNA levels were examined using real-time qPCR. Data are expressed the mean \pm SD. 
A

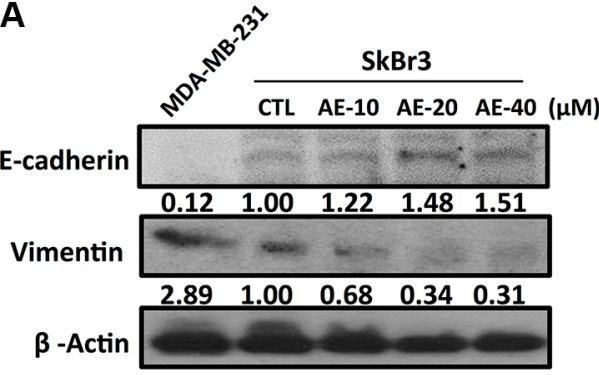

C

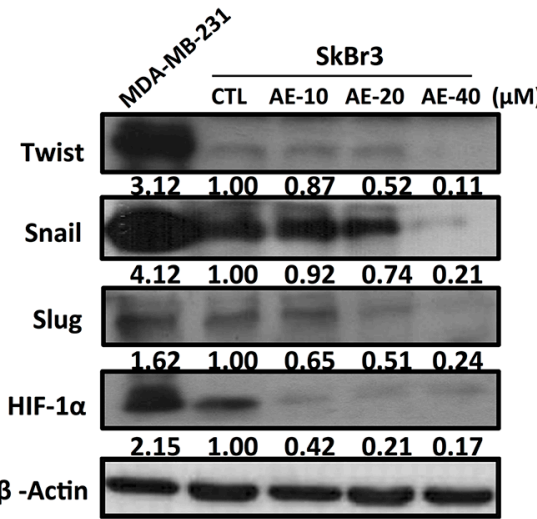

E

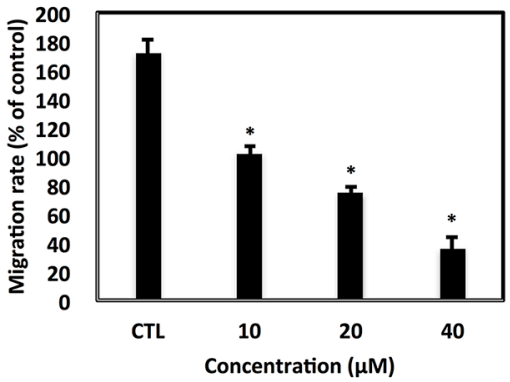

G

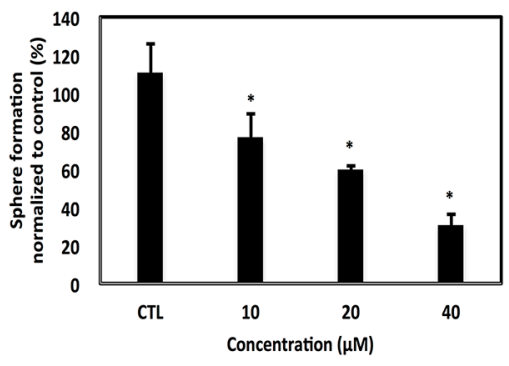

B

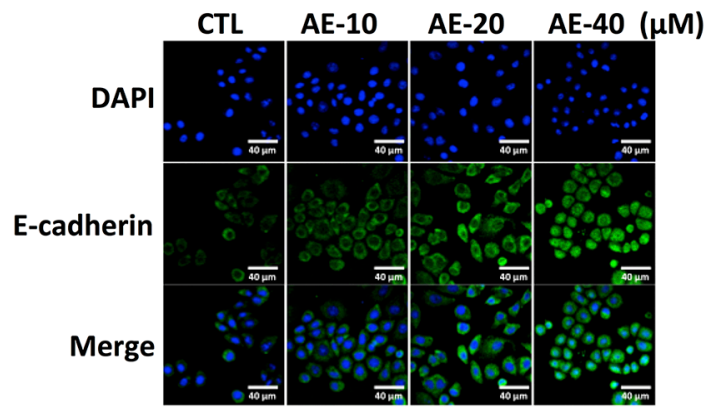

D

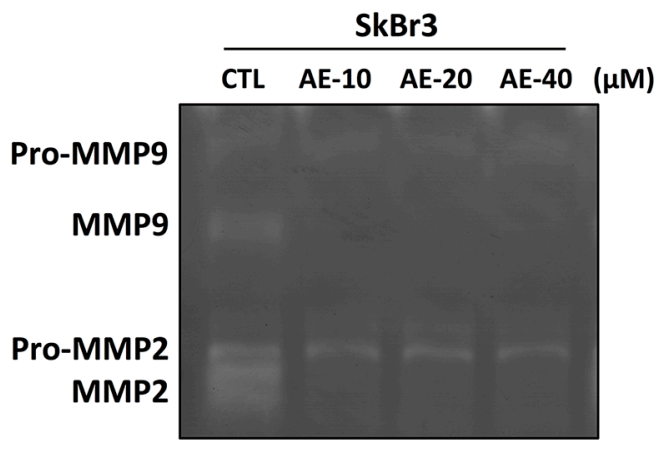

\section{$\mathbf{F}$}

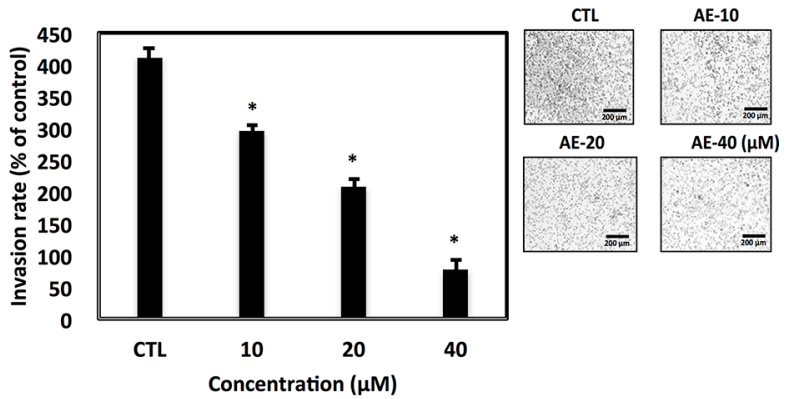

$\mathrm{H}$

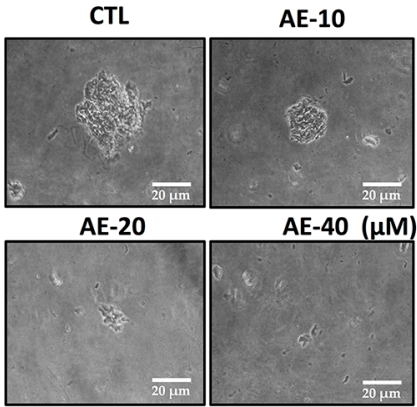

Figure 5: Aloe-emodin inhibited epithelial-mesenchymal transition in HER-2-overexpressing breast cancer cells. (A) $\mathrm{SkBr} 3$ cells treated with various concentrations of $\mathrm{AE}$ for $48 \mathrm{~h}$, the expression of epithelial cell marker E-cadherin and mesenchymal cell marker vimentin were assayed by Western blotting. (B) SkBr3 cells were treated with various concentrations of AE for $48 \mathrm{~h}$. E-cadherin was visualized through immunofluorescence staining using anti-E-cadherin antibodies (green). (C) SkBr3 cells treated with various concentrations of AE for $48 \mathrm{~h}$, the expression of transcription factor Twist, Snail, Slug, and HIF-1 $\alpha$ were assayed by Western blotting. Values represent relative protein abundance. MDA-MB-231 cells were used as the positive control. $\beta$-Actin was used as the loading control. (D) $\mathrm{SkBr} 3$ cells were cultured under serum-free conditions for $48 \mathrm{~h}$ under substrate-independent conditions on uncoated wells. Representative gelatin zymogram showing MMP9 and MMP2 activities. (E) SkBr3 cells were treated with various concentrations of AE cells for $24 \mathrm{~h}$. Migration ability of the cells were assayed $(* P<0.01)$. (F) SkBr3 cells were treated with various concentrations of AE cells for $16 \mathrm{~h}$. The invasion assay was assayed $(* P<0.05)$. (G) $\mathrm{SkBr} 3$ treated with various concentrations of $\mathrm{AE}$ for 7 days. The mammosphere-forming capacity was assayed $(* P<0.05)$. (H) Magnification, $\times 200$; Scale bar, $20 \mu \mathrm{m}$. Results are expressed as the number of mammospheres per 1000 seeded cells at 5 days (mean $\pm \mathrm{SD}, n=3$ ). 
A

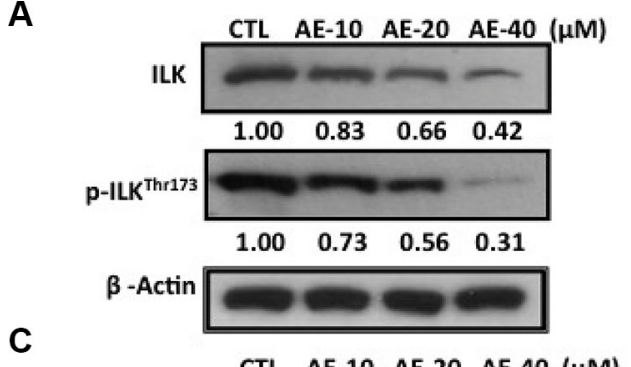

CTL AE-10 AE-20 AE-40 $(\mu \mathrm{M})$
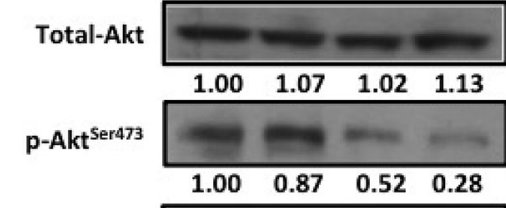

Total-mTOR
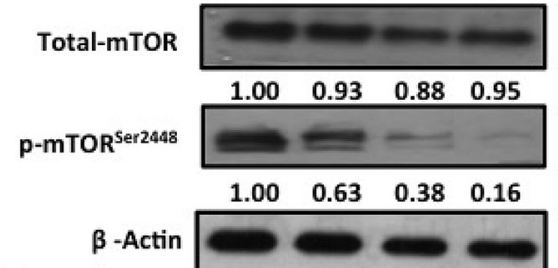

E

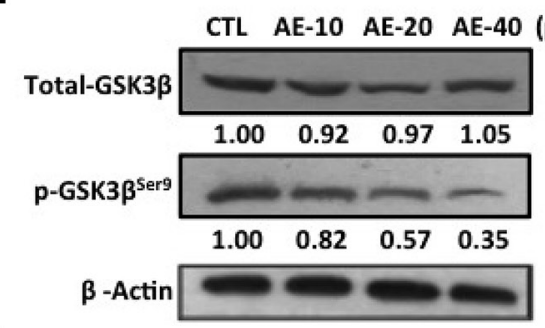

$\mathbf{F}$

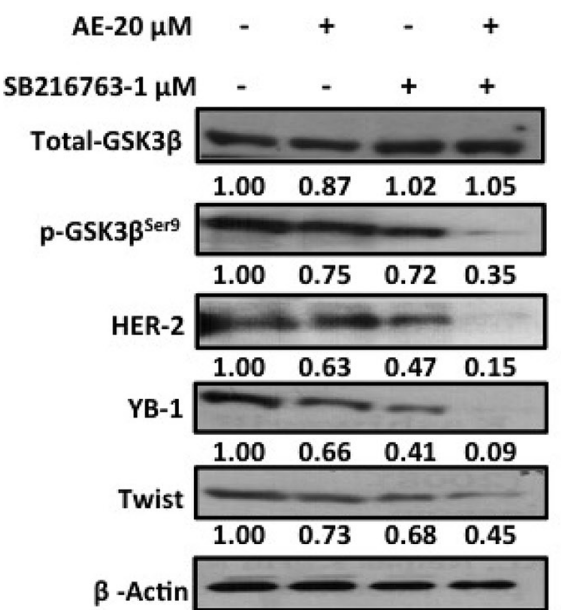

B

$\mathrm{AE}-20 \mu \mathrm{M}-\quad+\quad-\quad+$

Cpd22-300 nM - - + +
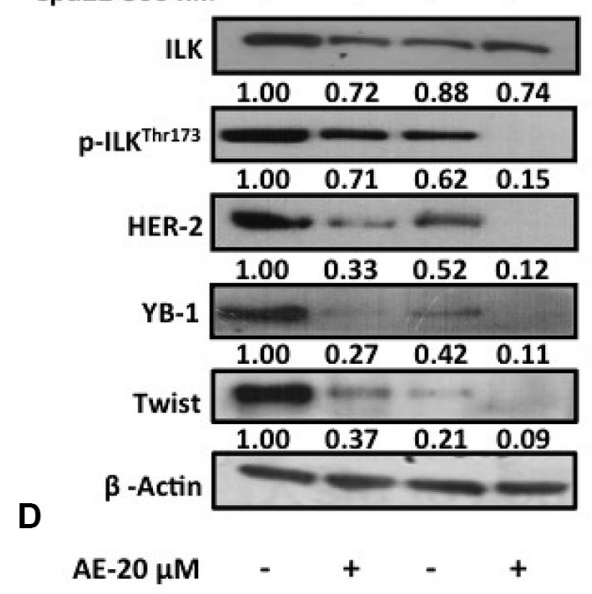

CA-Akt - $\quad-\quad+\quad+$

Total-Akt

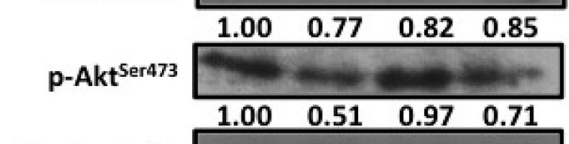

Total-mTOR

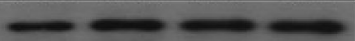

p-mTOR ${ }^{\text {Ser2448 }}$
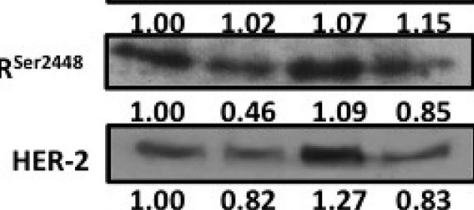

YB-1

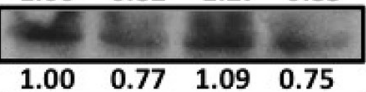

Twist

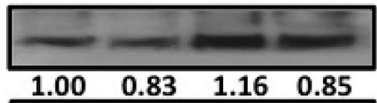

G

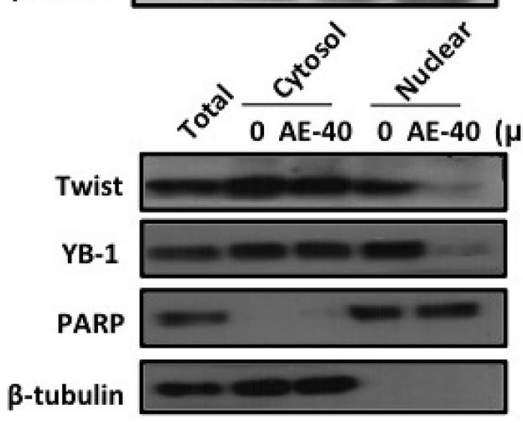

Figure 6: Aloe-emodin inhibited ILK signaling pathways in HER-2-overexpressing breast cancer cells. (A) $\mathrm{SkBr} 3$ cells were treated with various concentrations of AE for $48 \mathrm{~h}$. Cell lysates were immunoblotted with anti-ILK and anti-phospho-ILKThr173 antibody. (B) SkBr3 cells were treated with $20 \mu \mathrm{M} \mathrm{AE}$ or $300 \mathrm{nM}$ ILK inhibitor cpd-22 for $48 \mathrm{~h}$. Cell lysates were immunoblotted with antiILK, anti-phospho-ILKThr173, anti-HER-2, anti-YB-1, and anti-Twist antibodies. (C) $\mathrm{SkBr} 3$ cells were treated with various concentrations of AE for $48 \mathrm{~h}$. Cell lysates were immunoblotted with anti-phospho-AktSer473 and anti-phospho-mTORSer2448 antibodies. (D) $\mathrm{SkBr3}$ cells were transfected with constitutively active Akt and treated with $20 \mu \mathrm{M} \mathrm{AE}$ for $48 \mathrm{~h}$. Cell lysates were immunoblotted with antiphospho-AktSer473, anti-phospho-mTORSer2448, anti-HER-2, anti-YB-1, and anti-Twist antibodies. $\beta$-Actin was used as the loading control. (E) SkBr3 cells were then harvested and lysed for the detection of phospho-GSK3 $\beta$ Ser9 and $\beta$-Actin. (F) SkBr3 cells were treated with $20 \mu \mathrm{M} \mathrm{AE}$ or $1 \mu \mathrm{M}$ phospho-GSK3ßSer9 inhibitor SB216763 for $48 \mathrm{~h}$. Cell lysates were immunoblotted with anti-phosphoGSK3ßSer9, anti-HER-2, anti-YB-1, and anti-Twist antibodies. (G) SkBr3 cells were treated with $40 \mu \mathrm{M} \mathrm{AE}$ for $24 \mathrm{~h}$. Following cell fractionation, Twist and YB-1 content in the cytoplasmic or nuclear fraction was determined through Western blotting. PARP was used as the nuclear marker. $\beta$-Tubulin was used as the cytoplasmic marker. 
A

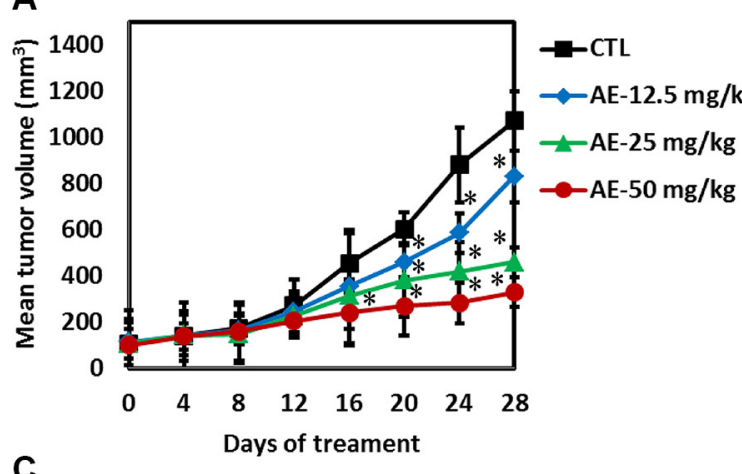

C

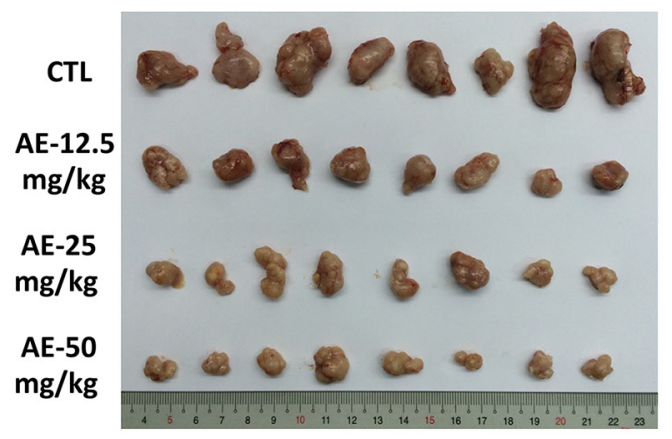

E

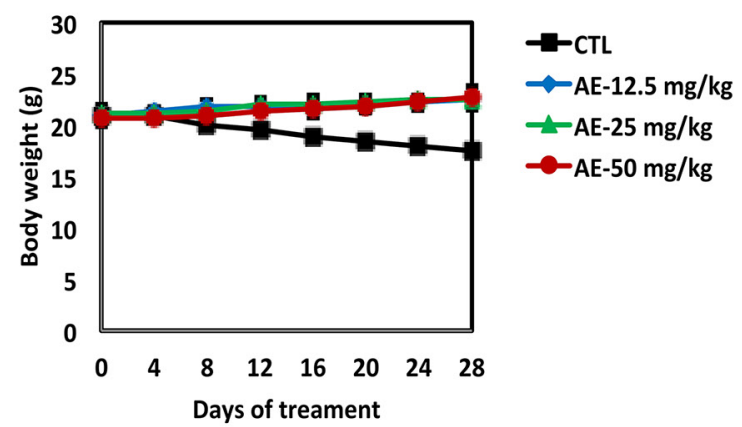

B
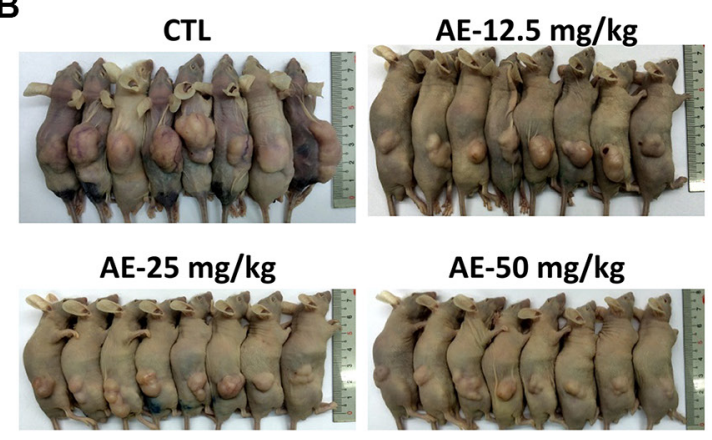

D

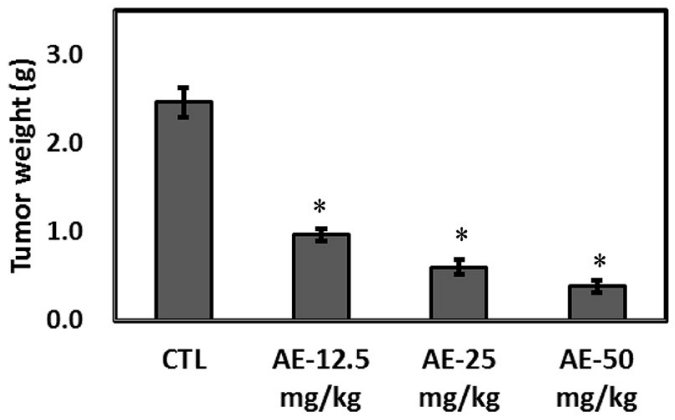

$\mathbf{F}$

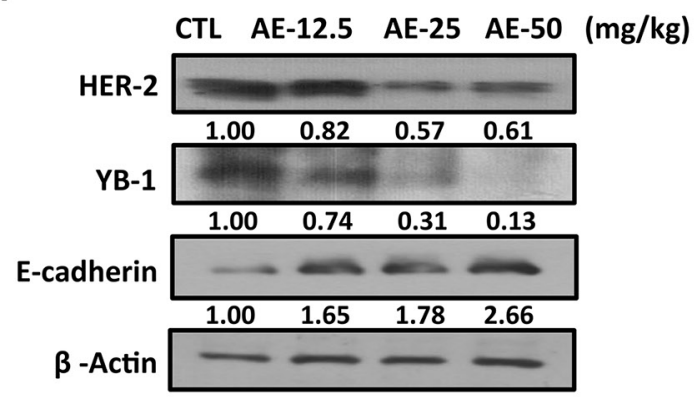

G

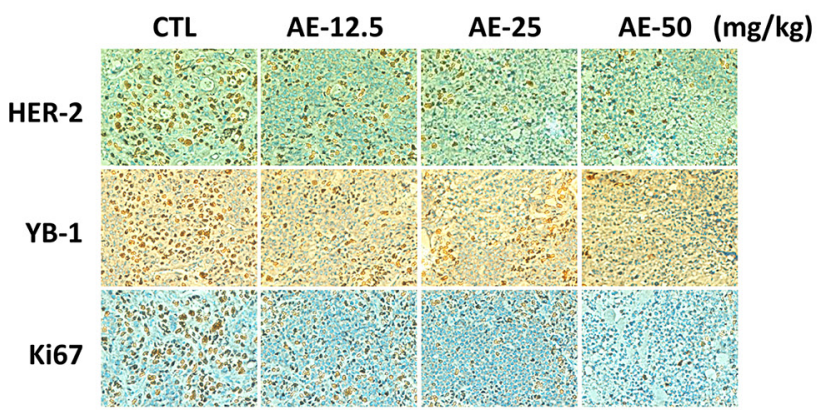

Figure 7: Effects of aloe-emodin on anti-tumor activity. (A) $\mathrm{SkBr} 3$ cells were used to establish xenografts in male BALB/c nude mice. Animals (six mice/group) were given control and AE (12.5, 25, and $50 \mathrm{mg} / \mathrm{kg}$ ) by i.p. injection 5 times for 14-18 days. Tumor size was monitored through serial caliper measurements twice a week. Each point represents mean tumor size \pm SE. (B) One representative mouse and its tumors are shown. (C) Representative tumors in each group are demonstrated. (D) Tumor weight was calculated as indicated in Materials and methods section. (E) Weekly body weight measurements indicated that therapy was not toxic. Each point represents mean \pm SE. (F) Tumor tissues were immunoblotted with anti-HER-2, anti-YB-1, and anti-E-cadherin antibodies. (G) Tumor tissue was collected at the conclusion of therapy, fixed in 10\% normal buffered formalin, and embedded in paraffin. Four-micron $(4 \mu \mathrm{M})$ sections of tumor tissue were assessed using immunohistochemistry for androgen receptor expression. Immunohistochemical analyses in xenograft tumors on day 28 after AE treatment were performed using antibodies against HER-2, YB-1, and Ki67. Magnification, $\times 40$; scale bar, $500 \mu \mathrm{M}$. 
Recent studies have shown that various characteristics of cancer stem cells, such as their high mobility, immune specificity, and metabolic specificity, differ considerably from our understanding of cancer cells; therefore, the development of cancer stem cell treatment is the future of cancer treatment [39-41]. The multifunctional protein YB-1 has been found in many cancers, with the common characteristics of promotion of stem cell marker expression, improvement of mobility, and enhancement of cancer drug resistance gene expression [42-45]. Therefore, the inhibition of YB-1 expression has attracted much attention. In this study, we confirmed that AE treatment significantly reduced YB-1 expression in HER-2-overexpressing cell lines (Figure 3).

EMT is a key event in cancer metastasis. Cancer metastasis is directly related to Twist gene transfection during cancer cell hypoxia [46]. Hypoxia of head and neck cancer most likely occurs if the transfection of the hypoxic gene HIF-1 $\alpha$ also results in the transfer of Twist and Snail genes, resulting in the worst prognosis in patients [47]. Hypoxia gene HIF-1 $\alpha$ overexpression can cause lung metastases in mice [48, 49]. Simultaneous expression of hypoxia gene HIF-1 $\alpha$ in head and neck cancer tumor tissues promotes the expression of Twist and Snail genes, leading to the worst prognosis $[50,51]$. This study confirmed that AE treatment significantly inhibited the oncogenic Twist expression (Figure 4). AE treatment significantly restored epithelial cell marker protein E-cadherin, inhibited the stromal cell marker protein vimentin, and suppressed EMTassociated transcription factors, including Twist, Snail, Slug, and HIF-1 $\alpha$, inhibiting EMT induction in cancer cells. Furthermore, we confirmed that AE significantly inhibited HER-2-overexpressing breast cancer cell migration and invasion. Interestingly, the stem cell experiments confirmed that AE effectively inhibited the growth of stem cells (Figure 5).

The PI3K/Akt/mTOR signal transduction pathway can regulate gene expression and is crucial in breast tumor cell growth proliferation, metastasis, and apoptosis $[52,53]$. ILK kinase activity and expression affect the activity of MMP-2 and MMP-9 [54, 55]. Studies have indicated that the inhibition of Akt activity leads to decreased activity of MMP-2 and MMP-9 (Figure 5D). This study confirmed that increasing concentrations of AE significantly inhibited the PI3K/Akt/mTOR signal transduction pathway. In particular, AE inhibited the oncogenic transcription factors Twist and YB-1 from entering the nucleus, thereby inhibiting downstream oncogenic protein expression (Figure 6).

In the xenograft model, $\mathrm{SkBr} 3$ cells were subcutaneously injected to $\mathrm{BALB} / \mathrm{c}$ nude mice and successfully induced subcutaneously tumors in BALB/c nude mice. Notably, compared with the control group, AE treatment for 28 days caused $80 \%$ inhibition of tumor growth; weight loss did not occur, thus confirming its low toxicity. Moreover, AE inhibited HER-2 and YB-1 expression in tumor tissue and restored E-cadherin expression (Figure 7).

In summary, the results indicated that $\mathrm{AE}$ inhibited the expression of HER-2 through the downregulation of YB-1. AE suppressed YB-1 expression through the downregulation of ILK/Akt/mTOR-regulated Twist expression in HER-2-overexpressing breast cancer cells (Figure 8). Importantly, AE treatment could be used for clinically treating patients with HER-2 overexpression in the future.

\section{Aloe-emodin}

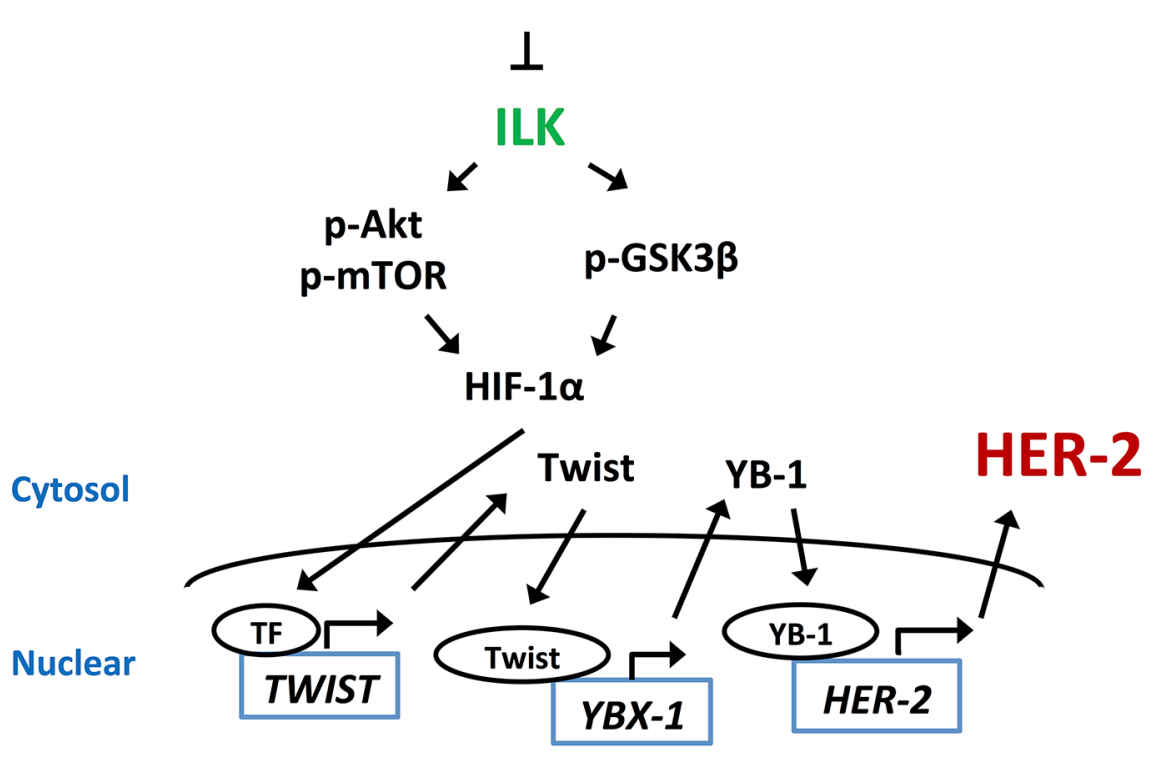

Figure 8: The signaling pathways of Aloe-emodin inhibits HER-2 expression. 


\section{MATERIALS AND METHODS}

\section{Materials}

Cell culture materials were obtained from Invitrogen (Burlington, Ontario, Canada). The reagents 3-(4,5-dimethylthiazol-2-yl)-2,5-diphenyl tetrazolium bromide (MTT), propidium iodide (PI) and the PureLink ${ }^{\text {TM }}$ HiPure Plasmid DNA Purification Kit were purchased from Sigma (St. Louis, MO, USA). Primary antibodies against PARP and Twist were purchased from GeneTex (Beverly, MA, USA). Anti-HER-2, anti-phospho-Akt (Ser473), anti-E-cadherin, anti-vimentin, anti-Snail, and anti-Slug antibodies were purchased from Cell Signaling (Beverly, MA, USA). Primary antibodies against ILK, phosphor-ILK (Thr173), phospho-mTOR (Ser2448), and phospho-GSK3 $\beta$ (Ser9) were purchased from Santa Cruz Biotechnology (Santa Cruz, CA, USA). Antibodies against YB-1 and $\beta$-Actin were purchased from Millipore (Temecula, CA, USA). The antibody against HIF-1 $\alpha$ was purchased from BD Biosciences Clontech (San Jose, CA, USA). For Western blotting, the secondary antibodies of horseradish peroxidase (HRP)-conjugated goat anti-mouse $\operatorname{IgG}$ and goat anti-rabbit IgG were obtained from Millipore (Temecula, CA, USA), and enhanced chemiluminescence (ECL) reagents were purchased from Sigma-Aldrich. Emodin, AE, and rhein were purchased from Sigma-Aldrich. The RNAi Consortium of YBX-1 was selected by the National RNAi Core Facility.

\section{Cell culture}

Human breast cancer cell lines SkBr3, BT-474, MDAMB-453, MCF-7, BT-20, MDA-MB-231 and human breast cell MCF-10A were obtained from the American Type Culture Collection (Manassas, VA, USA). Human breast cancer cell lines were cultured in Dulbecco's modified Eagle's medium (DMEM)/F12 and Roswell Park Memorial Institute (RPMI 1640) (Invitrogen, Carlsbad, CA, USA) supplemented with 10\% fetal bovine serum (FBS) and 1\% penicillin-streptomycin. Human breast cell MCF-10A was cultured in Dulbecco's modified Eagle's medium (DMEM)/ F12 supplemented with $5 \%$ horse serum, Insulin $10 \mu \mathrm{g} / \mathrm{mL}$, EGF $20 \mathrm{ng} / \mathrm{mL}$ and $1 \%$ penicillin-streptomycin. Cells were incubated at $37^{\circ} \mathrm{C}$ in an incubator containing $5 \% \mathrm{CO}_{2}$.

\section{MTT assay}

Cells were plated at $2 \times 10^{4}$ cells per well in triplicate in 24-well plates and incubated in a medium containing $10 \%$ FBS. After $24 \mathrm{~h}$ of incubation, the complete medium was replaced with the test medium containing vehicle control or various doses of emodin, AE, and rhein for 24, 48 , and $72 \mathrm{~h}$ at $37^{\circ} \mathrm{C}$. MTT solution (stock concentration: $5 \mathrm{mg} / \mathrm{mL}$ in PBS) was diluted to $500 \mu \mathrm{g} / \mathrm{mL}$. MTT working solution $(100 \mu \mathrm{L})$ was added to each well and incubated at $37^{\circ} \mathrm{C}$ for $2 \mathrm{~h}$. The absorbance was measured at $590 \mathrm{~nm}$ by using a $96-$ well plated reader.

\section{Cell cycle and annexin V-PI analysis}

Cell cycle and Annexin V-PI analysis were conducted as previously described [56].

\section{Western blotting}

Cells in 10-cm culture dishes $\left(1 \times 10^{6}\right.$ per dish $)$ were treated with the indicated drugs. After treatment, total proteins were extracted by adding $50 \mu \mathrm{L}$ cold lysis buffer (50 mM Tris-HCl, pH 7.4; 1mM NaF; $150 \mathrm{mM} \mathrm{NaCl}$; $1 \mathrm{mM}$ EGTA; $1 \mathrm{mM}$ phenylmethylsulfonyl fluoride; $1 \% \mathrm{NP}-40$; and $10 \mathrm{mg} / \mathrm{mL}$ leupeptin) to the cell pellets overnight at $-20^{\circ} \mathrm{C}$, followed by centrifugation at 12000 $\times g$ for 30 minutes. Western blotting was conducted as recently described [57].

\section{Cell transfection}

Cells were transfected with $50 \mathrm{nmol} / \mathrm{L}$ YBX-1-siRNA and cDNA-HER-2 using Oligofectamine (Invitrogen, Carlsbad, CA, USA) in a serum-free medium. Six hours after transfection, the medium was replaced with a medium supplemented with $10 \%$ FBS. After a 24 -h transfection, medium was replaced with a medium supplemented with $10 \%$ FBS with or without AE (10 or $20 \mu \mathrm{M})$, and the cells were incubated for $48 \mathrm{~h}$. After harvesting, the cells were lysed and prepared for Western blotting.

\section{Immunofluorescence}

Expression of HER-2, YB-1, Twist, and E-cadherin in the cells was analyzed through Leica confocal microscopy conducted using a monoclonal primary antibody [58].

\section{Colony formation assay}

$\mathrm{SkBr} 3$ cells were seeded into six-well plates with $2 \mathrm{~mL}$ culture medium containing $10 \%$ FBS. The colonies were counted after culturing in DMEM-F12 containing $10 \% \mathrm{FBS}$ at $37^{\circ} \mathrm{C}$ in a humidified, $5 \% \mathrm{CO}_{2}$ atmosphere. $\mathrm{SkBr} 3$ cells were washed twice with $\mathrm{PBS}$, stained with Giemsa, and colonies with $>50$ cells were counted.

\section{Soft agar assay}

SkBr3 cells were treated with $40 \mu \mathrm{M}$ emodin, $\mathrm{AE}$, and rhein or various doses of AE. Cells were suspended in a medium containing $0.4 \%$ agar and overlaid on $1 \%$ agar in 24-well plates ( 500 cells per well), respectively. After $2-3$ weeks, colonies were counted and photographed.

\section{Migration assay}

Cell monolayers were wounded using a sterile pipette tip and rinsed with PBS to remove cellular debris. 
Cells were treated with various doses of AE for $24 \mathrm{~h}$. The phase contrast images of the wounds were obtained at $37^{\circ} \mathrm{C}$ for incubation for 0 and $24 \mathrm{~h}$, and three separate experiments were performed.

\section{Invasion assays}

$\mathrm{SkBr} 3$ cell invasion assays were performed in $6.5-\mathrm{mm}$ Transwell chambers $(8.0-\mu \mathrm{m}$ pore size) (Coring Incorporation, NY, USA), and the polycarbonate filters were coated with diluted matrigel (BD Biosciences). $\mathrm{SkBr} 3$ cells without and with $\mathrm{AE}$ were added to the coated filters $\left(6 \times 10^{4}\right.$ cells per filter $)$ in $200 \mu \mathrm{L}$ serumfree DMEM-F12 in triplicate wells. DMEM-F12 medium containing $10 \%$ FBS was added to the lower chambers. After $24-\mathrm{h}$ incubation at $37^{\circ} \mathrm{C}$ in a $5 \% \mathrm{CO}_{2}$ and $95 \%$ humidity incubator, the cells that did not migrate and remained on the upper surface of the filter; they were wiped off using a cotton swab. Migrated cells were fixed in $95 \%$ alcohol for 10 minutes and stained with Giemsa for 10 minutes.

\section{Gelatin zymography assay}

Gelatin zymography was performed on protein extracts from the $\mathrm{SkBr} 3$ cells. In brief, the cells were rinsed three times with DPBS and cultured in $3 \mathrm{~mL}$ serum-free DMEM-F12 for $24 \mathrm{~h}$. The cells without and with AE were separated on $12.5 \%$ SDS-PAGE containing $1 \mathrm{mg} / \mathrm{mL}$ gelatin. Following electrophoresis at $48^{\circ} \mathrm{C}$, the gel was soaked in $2.5 \%$ Triton X-100 to remove SDS, rinsed three times in $\mathrm{H} 2 \mathrm{O}$, transferred to a bath containing $0.1 \mathrm{M}$ glycine- $\mathrm{NaOH}$ ( $\mathrm{pH} 8.3$ ), and incubated at $37^{\circ} \mathrm{C}$ for $16 \mathrm{~h}$. Subsequently, the gel was fixed, stained with $0.5 \%$ Coomassie blue in $30 \%$ isopropanol and 10\% acetic acid for $1 \mathrm{~h}$, and destained in $12.5 \%$ isopropanol and $10 \%$ acetic acid.

\section{Quantitative PCR assay}

RNA was isolated using the RNeasy ${ }^{\circledR}$ Plus Mini Kit (Qiagen, Valencia, CA). cDNA was amplified using gene-specific primers and the Power SYBR Green PCR Master Mix (Applied Biosystems). Reverse transcription of mRNA was performed using the RevertAid First Strand cDNA Synthesis Kit (Thermo Scientific) according to manufacturer instructions. mRNA expression was normalized to human $Y B X-1$ and TWIST1 expression. The results are presented as the relative fold expression compared with the respective control treatment.

\section{Nuclear extraction}

The cells were harvested, washed with PBS, and centrifuged at $700 \times g$ for 5 minutes; the supernatant was discarded. Cell pellets were first prepared in cytosolic extraction buffer with protease inhibitor and dithiothreitol
(DTT) and centrifuged at $16000 \times g$ for 10 minutes, and the supernatant was extracted as cytosolic fractions. Subsequently, cell pellets were prepared in NER buffer with protease inhibitor and DTT. After vortexing 4 times for 15 seconds, the cells were centrifuged at $16000 \times$ $g$ for 10 minutes, and the supernatant was extracted as nuclear fractions. All experiments were performed using the Nuclear/Cytosol Fractionation Kit (BioVision, Milpitas, CA, USA) according to manufacturer instructions. Proteins in the cytosolic and nuclear fractions were quantified through Bradford assays (Bio$\mathrm{Rad}$ ), and protein expression was measured through Western blotting.

\section{In vivo studies}

Female BALB/c nude mice (18-20 g; 6-8 weeks of age) were purchased from the National Animal Center (Taipei, Taiwan) and maintained in pressurized ventilated cage in accordance with institutional regulations. $\mathrm{SkBr} 3$ cells $\left(3 \times 10^{6}\right)$ were inoculated subcutaneous into the right flank of the mice. Seven days after inoculation, when tumor volumes were larger than $100 \mathrm{~mm}^{3}$, the mice were divided into four groups (six mice per group) and treated daily with vehicle alone and various doses of AE (12.5, 25 , and $50 \mathrm{mg} / \mathrm{kg}$ ). The mice were weighed, and their tumors were measured using calipers twice per week by using a digital caliper. The tumor volume was calculated using the following formula: (width $\times$ length $^{2}$ ) $/ 2$. On the final day of treatment, the mice were sacrificed; the tumors were excised, weighed, and sectioned; the tumor sections were embedded in an optimal cutting temperature (OCT) compound and frozen at $-70^{\circ} \mathrm{C}$.

\section{Immunohistochemical staining}

Sections frozen in OCT were fixed in acetone and chloroform. After overnight incubation with primary antibodies, including mouse monoclonal anti-HER-2, antiYB-1, and anti-E-cadherin, the slides were washed again with Tris-buffered saline and Tween 20 and incubated with biotinylated secondary antibodies and subsequently with the avidin-biotin-horseradish peroxidase complex (Vector Laboratories, San Mateo, CA, USA). Antibody detection was performed using 3,3'-diaminobenzidine, and the tissue sections were counterstained with Mayer's hematoxylin, washed, mounted with Universal Mount, and dried on a $56^{\circ} \mathrm{C}$ hot plate. The prepared slides were examined through light microscopy.

\section{Statistical analyses}

All values are expressed as mean \pm SD. Each value is the mean of at least three separate experiments in each group. The two-tailed Student $t$ test was used to compare the continuous variables between the two groups $(* P<0.05 ; * * P<0.01 ; * * * P<0.001)$. 


\section{ACKNOWLEDGMENTS AND FUNDING}

This study is supported in part by Taiwan Ministry of Health and Welfare Clinical Trial and Research Center of Excellence (MOHW105-TDU-B-212-133019).

\section{CONFLICTS OF INTEREST}

None.

\section{REFERENCES}

1. Guaoua S, Ratbi I, Lyahyai J, El Alaoui SC, Laarabi FZ, Sefiani A. Novel nonsense mutation of BRCA2 gene in a Moroccan man with familial breast cancer. Afr Health Sci. 2014; 14:468-471.

2. Lee HJ, Park IA, Song IH, Kim SB, Jung KH, Ahn JH, Ahn SH, Kim HH, Gong G. Comparison of pathologic response evaluation systems after anthracycline with/without taxanebased neoadjuvant chemotherapy among different subtypes of breast cancers. PloS ONE. 2015; 10:e137885.

3. Adamczyk A, Niemiec J, Janecka A, Harazin-Lechowska A, Ambicka A, Grela-Wojewoda A, Domagala-Haduch M, Cedrych I, Majchrzyk K, Kruczak A, Rys J, Jakubowicz J. Prognostic value of PIK3CA mutation status, PTEN and androgen receptor expression for metastasis-free survival in HER2-positive breast cancer patients treated with trastuzumab in adjuvant setting. Pol J Pathol. 2015; 66:133-141.

4. Christenson JL, Denny EC, Kane SE. t-Darpp overexpression in HER2-positive breast cancer confers a survival advantage in lapatinib. Oncotarget. 2015; 6: 33134-45. doi: 10.18632/oncotarget.5311.

5. Black JD, Lopez S, Cocco E, Bellone S, Altwerger G, Schwab CL, English DP, Bonazzoli E, Predolini F, Ferrari F, Ratner E, Silasi DA, Azodi $M$, et al. PIK3CA oncogenic mutations represent a major mechanism of resistance to trastuzumab in HER2/neu overexpressing uterine serous carcinomas. $\mathrm{Br} \mathrm{J}$ Cancer. 2015; 113: 1020-1026.

6. Hajighasemlou S, Alebouyeh M, Rastegar H, Manzari MT, Mirmoghtadaei M, Moayedi B, Ahmadzadeh M, Parvizpour F, Johari B, Naeini MM, Farajollahi MM. Preparation of Immunotoxin Herceptin-Botulinum and Killing Effects on Two Breast Cancer Cell Lines. Asian Pac J Cancer Prev. 2015; 16:5977-5981.

7. Takebe N, Warren RQ, Ivy SP. Breast cancer growth and metastasis: interplay between cancer stem cells, embryonic signaling pathways and epithelial-to-mesenchymal transition. Br J Cancer. 2011; 13:211.

8. Mimeault M, Batra SK. Hypoxia-inducing factors as master regulators of stemness properties and altered metabolism of cancer- and metastasis-initiating cells. J Cell Mol Med. 2013; 17:30-54.

9. Cammarata PR, Neelam S, Brooks MM. Inhibition of hypoxia inducible factor-1alpha downregulates the expression of epithelial to mesenchymal transition early marker proteins without undermining cell survival in hypoxic lens epithelial cells. Mol Vis. 2015; 21:1024-1035.

10. Ritter A, Friemel A, Fornoff F, Adjan M, Solbach C, Yuan J, Louwen F. Characterization of adipose-derived stem cells from subcutaneous and visceral adipose tissues and their function in breast cancer cells. Oncotarget. 2015; 6: 34475-93. doi: 10.18632/oncotarget.5922.

11. Fu P, Du F, Chen W, Yao M, Lv K, Liu Y. Tanshinone IIA blocks epithelial-mesenchymal transition through HIF-1alpha downregulation, reversing hypoxia-induced chemotherapy resistance in breast cancer cell lines. Oncol Rep. 2014; 31:2561-2568.

12. Wang W, Wang HJ, Wang B, Li Y, Qin Y, Zheng LS, Zhou JS, Qu PH, Shi JH, Zhang HS. The Role of the Y Box Binding Protein $1 \mathrm{C}$-Terminal Domain in Vascular Endothelial Cell Proliferation, Apoptosis, and Angiogenesis. DNA and Cell Biology. 2015.

13. Wu Y, Wang KY, Li Z, Liu YP, Izumi H, Yamada S, Uramoto H, Nakayama Y, Ito K, Kohno K. Y-box binding protein 1 expression in gastric cancer subtypes and association with cancer neovasculature. Clin Transl Oncol. 2015; 17:152-159.

14. Fotovati A, Abu-Ali S, Wang P-S, Deleyrolle LP, Lee C, Triscott J, Chen JY, Franciosi S, Nakamura Y, Sugita Y, Uchiumi T, Kuwano M, Leavitt BR, et al. YB-1 Bridges Neural Stem Cells and Brain Tumor-Initiating Cells via Its Roles in Differentiation and Cell Growth. Cancer Res. 2011; 71:5569-5578.

15. Xu M, Jin H, Xu CX, Sun B, Song ZG, Bi WZ,Wang Y. miR382 inhibits osteosarcoma metastasis and relapse by targeting Y box-binding protein 1. Mol Ther. 2015; 23:89-98.

16. Davies AH, Reipas KM, Pambid MR, Berns R, Stratford AL, Fotovati A, Firmino N, Astanehe A, Hu K, Maxwell C, Mills GB, Dunn SE. YB-1 transforms human mammary epithelial cells through chromatin remodeling leading to the development of basal-like breast cancer. Stem Cells (Dayton, Ohio). 2014; 32:1437-1450.

17. Hussain H, Al-Harrasi A, Al-Rawahi A, Green IR, Csuk R, Ahmed I, Shah A, Abbas G, Rehman NU, Ullah R. A fruitful decade from 2005 to 2014 for anthraquinone patents. Expert Opin Ther Pat. 2015; 25:1053-1064.

18. Zhao H, Darzynkiewicz Z. Attenuation of replication stressinduced premature cellular senescence to assess anti-aging modalities. Curr Protoc Cytom. 2014; 69:9.47.41-49.47.10.

19. Zhang L, Lau YK, Xia W, Hortobagyi GN, Hung MC. Tyrosine kinase inhibitor emodin suppresses growth of HER$2 /$ neu-overexpressing breast cancer cells in athymic mice and sensitizes these cells to the inhibitory effect of paclitaxel. Clin. Cancer Res. 1999; 5:343-353.

20. Zhang L, Lau YK, Xi L, Hong RL, Kim DS, Chen CF, Hortobagyi GN, Chang C, Hung MC. Tyrosine kinase inhibitors, emodin and its derivative repress HER-2/neuinduced cellular transformation and metastasis-associated properties. Oncogene. 1998; 16:2855-2863.

21. Ok S, Kim SM, Kim C, Nam D, Shim BS, Kim SH, Ahn KS, Choi SH, Ahn KS. Emodin inhibits invasion 
and migration of prostate and lung cancer cells by downregulating the expression of chemokine receptor CXCR4. Immunopharmacology and Immunotoxicology. 2012; 34:768-778.

22. Venturutti L, Romero LV, Urtreger AJ, Chervo MF, Cordo Russo RI, Mercogliano MF, Inurrigarro G, Pereyra MG, Proietti CJ, Izzo F, Diaz Flaque MC, Sundblad V, Roa JC, et al. Stat3 regulates ErbB-2 expression and co-opts ErbB2 nuclear function to induce miR-21 expression, PDCD4 downregulation and breast cancer metastasis. Oncogene. 2015.

23. Nishio S, Ushijima K, Yamaguchi T, Sasajima Y, Tsuda H, Kasamatsu T, Kage M, Ono M, Kuwano M, Kamura T. Nuclear Y-box-binding protein-1 is a poor prognostic marker and related to epidermal growth factor receptor in uterine cervical cancer. Gynecol Oncol. 2014; 132:703-708.

24. Gopal SK, Greening DW, Mathias RA, Ji H, Rai A, Chen M, Zhu HJ, Simpson RJ. YBX1/YB-1 induces partial EMT and tumourigenicity through secretion of angiogenic factors into the extracellular microenvironment. Oncotarget. 2015; 6:13718-13730. doi: 10.18632/oncotarget.3764.

25. Shiota M, Yokomizo A, Itsumi M, Uchiumi T, Tada Y, Song Y, Kashiwagi E, Masubuchi D, Naito S. Twist, Y-box-binding protein-1 promote malignant potential in bladder cancer cells. Br J Urol. 2011; 108:142-149.

26. He L, Che M, Hu J, Li S, Jia Z, Lou W, Li C, Yang J, Sun S, Wang H, Chen X. Twist contributes to proliferation and epithelial-to-mesenchymal transition-induced fibrosis by regulating YB-1 in human peritoneal mesothelial cells. Am J Pathol. 2015; 185:2181-2193.

27. Liu X, Yun F, Shi L, Li ZH, Luo NR, Jia YF. Roles of Signaling Pathways in the Epithelial-Mesenchymal Transition in Cancer. APJCP. 2015; 16:6201-6206.

28. Zhang W, Zhang T, Lou Y, Yan B, Cui S, Jiang L, Han B. Placental Growth Factor Promotes Metastases of Non-Small Cell Lung Cancer Through MMP9. Cell Physiol Biochem. 2015; 37:1210-1218.

29. Kalra J, Sutherland BW, Stratford AL, Dragowska W, Gelmon KA, Dedhar S, Dunn SE, Bally MB. Suppression of Her2/neu expression through ILK inhibition is regulated by a pathway involving TWIST and YB-1. Oncogene. 2010; 29:6343-56.

30. Pratap UP, Sharma HR, Mohanty A, Kale P, Gopinath S, Hima L, Priyanka HP, ThyagaRajan S. Estrogen upregulates inflammatory signals through NF-kappaB, IFN-gamma, and nitric oxide via Akt/mTOR pathway in the lymph node lymphocytes of middle-aged female rats. Int Immunopharmacol. 2015.

31. Erdogan B, Turkmen E, Yalta TD, Usta U, Kodaz H, Hacibekiroglu I, Tanriverdi O, Uzunoglu S, Cicin I. Importance of Ki-67 in human epidermal growth factor receptor 2 positive breast cancer. J Buon. 2015; 20:730-736.

32. Shetty P, Bargale A, Patil BR, Mohan R, Dinesh US, Vishwanatha JK, Gai PB, Patil VS, Amsavardani TS. Cell surface interaction of annexin A2 and galectin-3 modulates epidermal growth factor receptor signaling in Her-2 negative breast cancer cells. Mol Cell Biochem. 2015.
33. Chu Z, Lin H, Liang X, Huang R, Zhan Q, Jiang J, Zhou X. Clinicopathologic characteristics of typical medullary breast carcinoma: a retrospective study of 117 cases. PloS one. 2014; 9:e111493.

34. Liu AN, Sun P, Liu JN, Ma JB, Qu HJ, Zhu H, Yu CY, Zhang LM. Clinicopathologic characteristics and prognostic factors in patients with operable HER-2 overexpressing breast cancer. Asian Pac J Cancer Prev. 2012; 13:1197-1201.

35. Patki M, Salazar M, Trumbly R, Ratnam M. Differential effects of estrogen-dependent transactivation vs. transrepression by the estrogen receptor on invasiveness of HER2 overexpressing breast cancer cells. Biochem Bioph Res Co. 2015; 457:404-411.

36. Chun-Guang W, Jun-Qing Y, Bei-Zhong L, Dan-Ting J, Chong W, Liang Z, Dan Z, Yan W. Anti-tumor activity of emodin against human chronic myelocytic leukemia K562 cell lines in vitro and in vivo. Eur J Pharmacol. 2010; 627:33-41.

37. Zheng ZH, Hu JD, Chen YY, Lian XL, Zheng HY, Zheng J, Lin $\mathrm{MH}$. [Effect of emodin on proliferation inhibition and apoptosis induction in leukemic K562 cells]. [Article in Chinese]. Zhongguo shi yan xue ye xue za zhi. 2009; 17:1434-1438.

38. Pecere T, Sarinella F, Salata C, Gatto B, Bet A, Dalla Vecchia F, Diaspro A, Carli M, Palumbo M, Palu G. Involvement of p53 in specific anti-neuroectodermal tumor activity of aloeemodin. Int J Cancer. 2003; 106:836-847.

39. Rassouli FB, Matin MM, Saeinasab M. Cancer stem cells in human digestive tract malignancies. Tumour Biol. 2015; 37:7-21.

40. Zumwalt TJ, Goel A. Immunotherapy of Metastatic Colorectal Cancer: Prevailing Challenges and New Perspectives. Curr Colorectal Cancer Rep. 2015; 11:125-140.

41. Hirohashi Y, Torigoe T, Tsukahara T, Kanaseki T, Kochin V, Sato N. Immune Responses to Human Cancer Stem-like Cells/Cancer-initiating Cells. Cancer Sci. 2015; 107:12-17.

42. Mylona E, Melissaris S, Giannopoulou I, Theohari I, Papadimitriou C, Keramopoulos A, Nakopoulou L. Y-boxbinding protein 1 (YB1) in breast carcinomas: relation to aggressive tumor phenotype and identification of patients at high risk for relapse. Eur J Surg Oncol. 2014; 40:289-296.

43. Carter BZ, Mak PY, Mak DH, Ruvolo VR, Schober W, McQueen T, Cortes J, Kantarjian HM, Champlin RE, Konopleva M, Andreeff M. Synergistic effects of p53 activation via MDM2 inhibition in combination with inhibition of $\mathrm{Bcl}-2$ or $\mathrm{Bcr}-\mathrm{Abl}$ in $\mathrm{CD} 34+$ proliferating and quiescent chronic myeloid leukemia blast crisis cells. Oncotarget. 2015; 6:30487-30499. doi: 10.18632/ oncotarget.5890.

44. Shiota M, Bishop JL, Takeuchi A, Nip KM, Cordonnier T, Beraldi E, Kuruma H, Gleave ME, Zoubeidi A. Inhibition of the HER2-YB1-AR axis with Lapatinib synergistically enhances Enzalutamide anti-tumor efficacy in castration resistant prostate cancer. Oncotarget. 2015; 6:9086-9098. doi: 10.18632/oncotarget.3602. 
45. Cybulski M, Jarosz B, Nowakowski A, Jeleniewicz W, Kutarska E, Bednarek W, Stepulak A. Cyclin A correlates with YB1, progression and resistance to chemotherapy in human epithelial ovarian cancer. Anticancer Res. 2015; 35:1715-1721.

46. Azimi I, Beilby H, Davis FM, Marcial DL, Kenny PA, Thompson EW, Roberts-Thomson SJ, Monteith GR. Altered purinergic receptor-Ca signaling associated with hypoxiainduced epithelial-mesenchymal transition in breast cancer cells. Mol Oncol. 2015.

47. Yang YJ, Na HJ, Suh MJ, Ban MJ, Byeon HK, Kim WS, Kim JW, Choi EC, Kwon HJ, Chang JW, Koh YW. Hypoxia Induces Epithelial-Mesenchymal Transition in Follicular Thyroid Cancer: Involvement of Regulation of Twist by Hypoxia Inducible Factor-1alpha. Yonsei Med J. 2015; 56:1503-1514.

48. Nakajima T, Anayama T, Koike T, Shingyoji M, Castle L, Kimura H, Yoshino I, Yasufuku K. Endobronchial ultrasound doppler image features correlate with mRNA expression of HIF1-alpha and VEGF-C in patients with non-small-cell lung cancer. J Thorac Oncol. 2012; 7:1661-1667.

49. Chen J, Lan T, Zhang W, Dong L, Kang N, Zhang S, Fu M, Liu B, Liu K, Zhan Q. Feed-Forward Reciprocal Activation of PAFR and STAT3 Regulates Epithelial-Mesenchymal Transition in Non-Small Cell Lung Cancer. Cancer Res. 2015; 75:4198-4210.

50. Wheeler SE, Suzuki S, Thomas SM, Sen M, Leeman-Neill RJ, Chiosea SI, Kuan CT, Bigner DD, Gooding WE, Lai SY, Grandis JR. Epidermal growth factor receptor variant III mediates head and neck cancer cell invasion via STAT3 activation. Oncogene. 2010; 29:5135-5145.

51. Kim JH, Hwang YJ, Han SH, Lee YE, Kim S, Kim YJ, Cho JH, Kwon KA, Kim JH, Kim SH. Dexamethasone inhibits hypoxia-induced epithelial-mesenchymal transition in colon cancer. World J Gastroenterol. 2015; 21:9887-9899.

52. Ji Y, Di W, Yang Q, Lu Z, Cai W, Wu J. Inhibition of Autophagy Increases Proliferation Inhibition and Apoptosis Induced by the PI3K/mTOR Inhibitor NVP-BEZ235 in Breast Cancer Cells. Clin Lab. 2015; 61:1043-1051.
53. Kumar D, Das B, Sen R, Kundu P, Manna A, Sarkar A, Chowdhury C, Chatterjee M, Das P. Andrographolide Analogue Induces Apoptosis and Autophagy Mediated Cell Death in U937 Cells by Inhibition of PI3K/Akt/mTOR Pathway. PloS ONE. 2015; 10:e0139657.

54. LotfiA, Mohammadi G, Saniee L, Mousaviagdas M, ChavoshiH, Tavassoli A. Serum Level of Matrix Metalloproteinase-2 and -9 in Patients with Laryngeal Squamous Cell Carcinoma and Clinical Significance. Asian Pacific Journal of Cancer Prevention: APJCP. 2015; 16:6749-6751.

55. Chou YC, Chang MY, Wang MJ, Yu FS, Liu HC, Harnod T, Hung $\mathrm{CH}$, Lee HT, Chung JG. PEITC inhibits human brain glioblastoma GBM 8401 cell migration and invasion through the inhibition of uPA, Rho A, and Ras with inhibition of MMP-2, -7 and -9 gene expression. Oncol Rep. 2015; 34:2489-2496.

56. Jou YJ, Chen CJ, Liu YC, Way TD, Lai CH, Hua CH, Wang CY, Huang SH, Kao JY, Lin CW. Quantitative phosphoproteomic analysis reveals gamma-bisabolene inducing p53-mediated apoptosis of human oral squamous cell carcinoma via HDAC2 inhibition and ERK1/2 activation. Proteomics. 2015; 15:3296-3309.

57. Lin YC, Lin JC, Hung CM, Chen Y, Liu LC, Chang TC, Kao JY, Ho CT, Way TD. Osthole inhibits insulin-like growth factor-1-induced epithelial to mesenchymal transition via the inhibition of PI3K/Akt signaling pathway in human brain cancer cells. J Agric Food Chem. 2014; 62: 5061-5071.

58. Way TD, Huang JT, Chou $\mathrm{CH}$, Huang $\mathrm{CH}$, Yang $\mathrm{MH}$, Ho CT. Emodin represses TWIST1-induced epithelialmesenchymal transitions in head and neck squamous cell carcinoma cells by inhibiting the beta-catenin and Akt pathways. Eur J Cancer. 2014; 50:366-378. 